\title{
Aufsätze/Essays
}

\section{New Research on Ptolemaeus Gnosticus}

\author{
by Christoph Markschies
}

To Wilhelm Schneemelcher, August 21, 1999, with gratitude

Seven years ago, I published an interpretation of the ten preserved fragments of Roman theologian Valentinus and introduced the most important results in Oxford at the $11^{\text {th }}$ International Conference in $1991^{2}$. In that work, I first tried to understand Valentinus exclusively out of his own texts - Valentinus, who usually is said to be founder of the branch of Valentinian Gnosticism which is named after him, and whose fragments have been interpreted in the light of different versions of the Valentinian system. This means that an utterly elementary rule of textinterpretation was applied to the short passages which were mainly recorded by Clement of Alexandria and Hippolytus. The title of the monography, "Valentinus Gnosticus?" signals that I intended to create a distinct image of a not very sharp figure as an original Christian thinker of the second century and to reconstruct his teachings as one variety of Alexandrine Theology located between Philo and Clement.

A premise for this kind of interpretation however is that one does not ascribe anonymous treatises such as the so-called Evangelium Veritatis to Valentinus, and that one does not take the statements of the later antiheretic authors of the established church Irenaeus, Clement and Hippolytus concerning Valentinus too seriously. I believe to have given detailed reasons for this kind of proceeding then. Recent attempts to ascribe texts ${ }^{3}$

1 The following contribution was presented in a shorter version to the "Berliner koptischgnostischer Arbeitskreis" on June 2S, 1999 and as a "master theme" at the 13th International Conference on Patristic Studies in Oxford, August 20, 1999. I wish to thank all participants in the ensuing discussion, especially Henry Chadwick and Mark Edwards, for their helpfull comments, and also Winrich Löhr. For the translation I would like to thank my assistant, Ulrike Kugler. The Greek text of Ptolemy's Epistle to Flora (CPG I, 1135 ) is cited according to the manuscript of a new edition, which I am going to publish in the next years. For this reason I have restricted the notes and given only the necessary documentations.

2 Ch. Markschies, Valentinus Gnosticus? Untersuchungen zur valentinianischen Gnosis mit einem Kommentar zu den Fragmenten Valentins, WUNT 65, Tübingen 1992; id., Das Problem des historischen Valentin - Neue Forschungen zu Valentinus Gnosticus, in: Papers presented at the 11 th International Conference on Patristic Studies held in Oxford 1991. Historica, Theologica et Philosophica, Gnostica, ed. by E.A. Livingstone, StPatr XXIV, Leuven 1993, 382-389.

3 P. Schüngel, Ein gnostisches Credo - in Stein gehauen!, RQ 93, 1998, 145-155 (on the 
such as the Evangelium Veritatis to Valentinus again would not convince me. Nor would another objection raised: The question whether Irenaeus and his successors wrote the truth about Valentinus or whether they must be called liars, seems to work with far too simplified alternatives ${ }^{5}$. In fact, Irenaeus hardly knew anything about Valentinus, and Clement and Hippolytus only knew fragments of texts from a later Valentinian commentary. And all these authors presented their versions of the history of Valentinianism to the best of their knowledge and belief - however, as we said, with a clear antiheretic impetus. Thus one can neither call them "liars" nor copy their version of the history of development of Valentinian Gnosticism on a scale of 1:1 for a modern monography.

The papers on the fragments of Valentinus that have been published during the last years ${ }^{6}$, will not be commented on here. Instead, I will rectify in a first approach a fundamental shortcoming of my monography of the year 1992: "Valentinus Gnosticus?" concentrates on one single figure and the monography is only groundwork for a modern history of the development of Valentinian Gnosticism in so far as - according to what has been shown - the main period of formation of what we call "Valentinian Gnosticism" must have been after the middle of the fifties of the first century. I have pointed out "moments of crisis" in Valentinus' theology and I also have drawn an outline of the development of the school?. But the comments given in broad outline still ask for a more detailed presentation and argumentation, something which I would like to present in the course of the following years. At the Congress of the "Society of Biblical Literature" held on the occasion of the $50^{\text {th }}$ anniversary of the Nag-Hammadi texts, I already tried to present a first building block of a history of development of Valentinian Gnosticism by talking on

Roman Inscription ICUR VI, 297a: Ch. Markschies, Valentinus Gnosticus? [see note 21, 393).

4 See J. Helderman, A Christian Gnostic Text. The Gospel of Truth, in: Gnosis and Hermeticism from Antiquity to Modern Times, ed. by R. van den Broek and W.J. Hanegraaff, SUNY Series in Western Esoteric Traditions, Albany 1998, 53-68.

5 G. Quispel, Valentinus and the Gnostikoi, VigChr 50, 1996, 1-4; see Ch. Markschies, Nochmals: Valentinus und die Gnostikoi. Beobachtungen zu Irenaeus, haer. I 30,15 und Tertullian, Val. 4,2, VigChr 51, 1997, 179-187.

6 Selected examples: M. Görg, Bythos und Nun: Zur ägyptischen Basis einer altchristlichgnostischen Gottesidee, in: Meilenstein. Festgabe für Herbert Donner, ed. by M. Weippert and St. Timm, ÄAT 30, Wiesbaden 1995, 52-59; J. Holzhausen, Gnosis und Martyrium. Zu Valentins viertem Fragment, ZNW 85, 1994, 116-131; P. Schüngel, Gnostische kontra neutestamentliche Soteriologie. Zu Valentins viertem Fragment, VigChr S0, 1996, 257-265.

7 Ch. Markschies, Valentinus Gnosticus? (see note 2), 392-402; see also id., Die Krise einer philosophischen Bibel-Theologie in der Alten Kirche, oder: Valentin und die valentinianische Gnosis zwischen philosophischer Bibelinterpretation und mythologischer Häresie, in: A. Böhlig/Ch. Markschies, Gnosis und Manichäismus. Forschungen und Studien zu Valentin und Mani sowie zu den Bibliotheken von Nag Hammadi und Medinet Madi, BZNW 72, Berlin/New York 1994, 1-37. 
the common grounds and differences between the "school of Valentinus" and a philosophical school of his times. ${ }^{8}$. Here, I would like to continue my work by commenting on the earliest text - after the fragments of Valentinus - that can be considered for a developmental history of Valentinian Gnosticism. I will comment on "Ptolemy's Epistle to Flora", known from Epiphanius of Salamis. Here again, I will first try to interprete the text out of itself. It is only in a second step that I will consider further information on its author Ptolemy. This proceeding fundamentally stands out against the latest extensive interpretation of this Epistle, which has been presented by Gilles Quispel in his critical text edition and commentary published in "Sources Chrétiennes", second edition, 1966". I take up two recent studies by Winrich Löhr ${ }^{10}$, who is teaching Patristics at Cambridge, and a rarely noticed work by Almut Rütten ". I do not wish by any means to diminuate the merits of the commentatory edition by Quispel; anybody who has studied the complicated tradition of Epiphanius' text and who is aware of the problems of Karl Holl's Berlin-edition will respect Quispel's efforts to work himself through the jungle of conjectured versions at the least for philological reasons. Even text-interpreters who do not agree with Quispel will happily use the rich material of his commentary.

My own interpretation differs from Quispel's standard-setting work in two fundamental points: In his introduction, Quispel designates it as one task of his commentation to mark those differences, "qui ... distinguent de l'opinion catholique les idées de notre gnostique"12. This means that a precise distinction between "catholic" and "gnostic" positions in the middle of the second century is taken for granted, something which must be regarded as highly problematic, all the more after the publication of Walter Bauer's work "Rechtgläubigkeit und Ketzerei im ältesten Christentum"13,

8 Ch. Markschies, Valentinian Gnosticism: Toward the Anatomy of a School, in: The Nag Hammadi Library after Fifty Years. Proceedings of the 1995 Society of Biblical Literature Commemoration, ed. by J.D. Turner and A.M. McGuire, NHS 44, Leiden 1997, 401-438.

Ptolémée, Lettre à Flora, Analyse, texte critique, traduction, commentaire et index grec de G. Quispel, SC 24 ${ }^{\text {bis }}$, Paris 1966.

10 W.A. Löhr, La doctrine de Dieu dans la lettre à Flora de Ptolémée, RHPR 75, 1995, 177. 191; id., Die Auslegung des Gesetzes bei Markion, den Gnostikern und den Manichäern, in: Stimuli. Exegese und ihre Hermeneutik in Antike und Christentum. FS für Ernst Dassmann, ed. by G. Schöllgen and C. Scholten, JbAC, suppl., 23, Münster 1996, 77-95; and id., Art. Ptolemäus, TRE 27, Berlin/New York 1997, 699-702.

11 A. Rütten, Der Brief des Ptolemaeus an Flora. Ein Beispiel altkirchlicher Gesetzesauslegung in Auseinandersetzung mit Marcion, in: Christlicher Glaube und religiöse Bildung. Frau Prof.Dr. Friedel Kriechbaum zum 60. Geburtstag am 13. August 1995, ed. by H. Deuser and G. Schmalenberg, Gießener Schriften zur Theologie und Religionspädagogik 11, Gießen 1995, 53-74.

12 G. Quispel, Ptolémée, Lettre à Flora (see note 9), 10.

13 W. Bauer, Rechtgläubigkeit und Ketzerei im ältesten Christentum. 2nd revised ed. with a postscript ed. by G. Strecker, BHTh 10, Tübingen 1964; English: W. Bauer, Orthodoxy and Heresy in Earliest Christianity, Philadelphia 1971. - A report of the extensive discussions held on that work cannot be subject to this paper. 
although Quispel still used his differentiation in publications of the nineties ${ }^{14}$. Quispel further intends to collect the passages, "qui relient les theories exprimées dans l'Épitre aux idées fondamentales du système de Ptolémée et du système valentinien en général ${ }^{\text {15 }}$. I for my part however will - in the second part of this contribution - put the question whether a "système de Ptolémée" has been handed down to us at all, with which the systematic thoughts of this Epistle could be compared.

In the first part of this contribution, I will reflect upon Ptolemy's Epistle to Flora and talk on a) its literary genre, b) its theory of legislation c) its theory of the principles as well as on the inner connection between the latter two topics. Only in the second part will I try to relate a number of other statements on the author of the Epistle to the results of our interpretation of Ptolemy's Epistle to Flora.

\section{(I) On Ptolemy's Epistle to Flora}

\section{(Ia) The genre of the text}

Surprisingly enough, no study has been made on the seemingly simple question of the genre of Ptolemy's Epistle to Flora. If you take Quispel's work for example, an analysis is put in front of the text edition and the commentary, which, besides other issues, studies "sujet et caractère de l'écrit"16. But comments on form and genre of the text are missing, possibly because up to recent years it was not disputed that the text was a private letter written by an author to a female individual called Flora ${ }^{17}$. Winrich Löhr was the first person to draw the attention to the argumentative technique of the Epistle and he characterized it rightly with the term

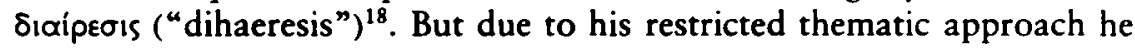

14 G. Quispel, Valentinus and the Gnostikoi (see note 5), 1-4. The term "church-Christians" ("Kirchenchristen"), which is used frequently, is equally inappropriate. It meets the claims of the group appointed by the term that Gnostics do not form part of the true church, but it does not meet with the way the - thus excluded - group sees itself.

15 G. Quispel, Ptolémée, Lettre à Flora (see note 9), 10; see also W. Foerster, Die Grundzüge der ptolemaeischen Gnosis, NTS 6, 1959, (16-31) 16, who states that Ptolemy's Epistle to Flora, as well as an interpretation of the Prologue of St. John's Gospel cited by Irenaeus and Herakleon's numerous fragments, all show the same system or at least one that is very similar.

16 G. Quispel, Ptolémée, Lettre à Flora (see note 9), 11-12.

17 It was only R.M. Grant, who suggested in a short article (Notes on Gnosis 2. Ptolemaeus to Flora, VigChr 11,1957, 147f.) that Flora was a secret name for the Christian established church in the city of Rome. This was disproved by G. Lüdemann, Zur Geschichte des ältesten Christentums in Rom. I. Valentin und Marcion II. Ptolemäus und Justin, ZNW 70, 1979, (86-114) 106 note 62.

18 W.A. Löhr, Die Auslegung des Gesetzes bei Markion (see note 10), 80 note 12: "Die dihäretische Methode des Ptolemaeus könnte platonisch beeinflußt sein"; see also J. Mansfeld, Heresiography in Context. Hippolytus' Elenchos as a Source for Greek Philosophy, PhAnt 56, Leiden 1992, 279116. 
did not draw any consequences out of this observation for the determination of the genre.

But before the notion of sıaipeors can be utilized for the analysis of the genre of the Epistle, a closer look at the notion of "private letter" seems necessary: doubtless, Ptolemy's treatise to Flora is a letter addressed to an individual, even if almost all stilistic elements of a letter have been removed from the text in its form preserved by Epiphanius: it does not have a prescript, neither a prooemium nor an explicit ending. Only the corpus of the letter has come down to us ${ }^{19}$. But other preserved letters of the second and third century show that often the salutation of the addressee is repeated at the beginning of the corpus of a letter so that it can be assumed with good reason that the beginning of the citation in Epiphanius' treatise was the true beginning of the corpus of the epistle ${ }^{20}$.

But all this does not mean that we are dealing with a "private letter" in the modern sense of the term. The fact that copies of the Epistle circulated, that reached the bishop of Salamis in Cyprus in the late fourth century, shows, together with many other hints in the text that it was a "literary letter" and not at all a "non-literary" everyday text ${ }^{21}$. When searching for letters of this literary type that could be compared to our Epistle, first philosophical epistles come to mind, such as written by Epicurus or Porphyry to individuals like Menoeceus or Marcella. Unlike Epicurus' Epistle to Menoeceus or Porphyry's Epistle to Marcella ${ }^{22}$, Ptolemy's Epistle to Flora is not a protreptic epistle that would also winningly inform about basic ideas of Epicurean Philosophy and introduce a certain system of teachings or a certain form of living. As W. Löhr stated correctly, the Epistle to Flora is an epistle that names, discusses and solves one theological problem. This means that comparable texts cannot be found

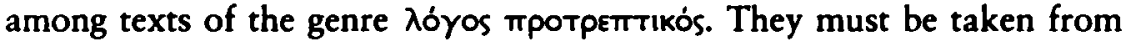
the genre of the $\varepsilon l \sigma a \gamma \omega \gamma \eta^{23}$. Ptolemy's Epistle to Flora is formed after the

Terminology taken from H.-J. Klauck, Die antike Briefliteratur und das Neue Testament, UTB 2022, Paderborn u.a. 1998, 36-40.

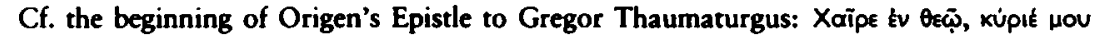

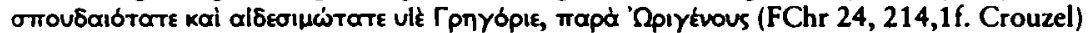

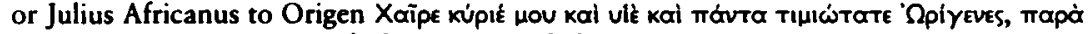

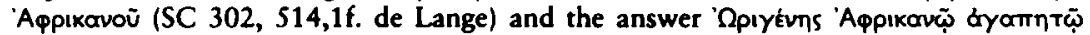

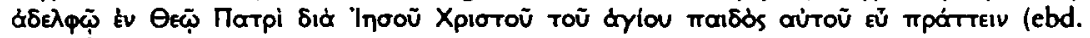
522,1f.).

For this differentiation see H.-J. Klauck, Die antike Briefliteratur (see note 19), $72 f$.

Porphyrios, Moós Mapké $\lambda \lambda a n$. Greek text, ed., transl., with introduction and comments by W. Pötscher, PhAnt 15, Leiden 1969; K. Alt, Glaube, Wahrheit, Liebe, Hoffnung bei Porphyrios, in: Die Weltlichkeit des Glaubens in der Alten Kirche. FS für U. Wickert zum siebzigsten Geburtstag, in collaboration with B. Aland and Ch. Schäublin ed. by D. Wyrwa, BZNW 85, Berlin/New York 1997, 25-43.

23 See M. Asper, Zur Struktur und Funktion eisagogischer Texte, in: W. Kullmann/J. Althoff/M. Asper (Eds.), Gattungen wissenschaftlicher Literatur in der Antike, Tübingen 1998, 309-340. 
philosophical epistle of the eirorywyij. One can endeavour to determine the genre of the Epistle even further by differentiating (following Markus Asper) three types of eisagogical texts: catechetic eioorwyai written in dialogue form, eioorwyai written in the style of a scholium and finally

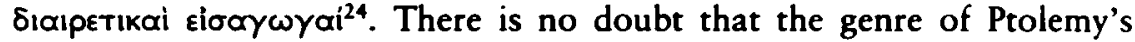
Epistle belongs to the subdivision of "dihaeretic" introductions, as the Epistle shows clear marks of the method of siaipeors, which are: the descending in subdivisions from the most common to the most detailed term of the respective subject or technical problem of a subject, while the specific differences between all the terms of the respective "dihaeresis" are made explicit ${ }^{25}$.

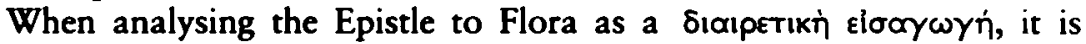
obvious that the form of the epistle exactly meets the demands of the genre as regards style and content. These demands are made explicit for example in the Quaestiones medicinales of Pseudo-Soranus' ${ }^{26}$. In accordance with the demands of the genre, Ptolemy's Epistle includes a clear explanation of the problem (demonstratio), an appropriate selection (primae rationes) and the necessary brevity (modicus) ${ }^{27}$. This orientation towards the demands of the genre of the eloorwy' could be shown more detailed in comparison with relevant texts of Ptolemy's contemporaries Galen and Nicomachus of Gerasa as well as Porphyry. In the opening of Ptolemy's Epistle, the aim of the argumentation is given implicitely: The ability of understanding the law established by Moses, which - I cite - not many

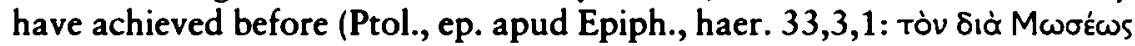

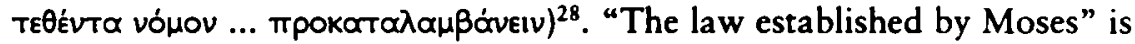

24 M. Asper, Zur Struktur und Funktion eisagogischer Texte (see note 23), 315-326.

25 F.P. Hager, Art. Dihairesis, HWPh 2, Basel/Stuttgart 1972, 242-244 and H. Peters, Art. Dihaerese, HWRh 2, Tübingen 1994, 748-753.

26 See Ps.-Soranus, quaest. 21/prol. quid est isagogia? Isagogia est introductio doctrinae cum demonstratione primarum rationum ad medicinae artis conceptionem ... tractatus quidem introductorius est modicus babendus $(251,8 \mathrm{f} . / 244,6$ Rose). - I cite the text from the edition by V. Rose, Anecdota Graeca et Graecolatina. Mitteilungen aus Handschriften zur Geschichte der griechischen Wissenschaft, Vol. 2, Amsterdam 1963 (= Berlin 1870), 241-274.

27 So it were neither detailed academic manuals (ourypáunorta), nor an even shorter enchiridion (Exxeıploıv).

28 It is important to note that "many" were supposed to have had the wrong cognition of

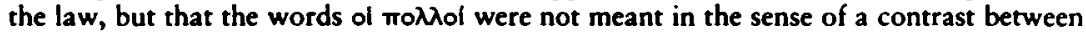
the uneducated established church and the clever Valentinians - contrary to what Harnack says: "Zwar die $\pi 0 \lambda \lambda$ ol sind im Irrthum, sie haben eine falsche Erkenntniss; ... aber sie werden doch so respectirt, dass ihnen, wie es scheint, sogar apostolische Überlieferung zugestanden wird. Ptolemäus vermeidet es, sie überhaupt zu nennen (vielleicht sind sie unter den tives c. 3,14 [=5,13] zu verstehen)". A.v. Harnack, Der Brief des Ptolemäus an die Flora, SPAW.PH 1902, (507-545) 531 = id., Kleine Schriften zur alten Kirche. Bd. 1 Berliner Akademieschriften 1890-1907 mit einem Vorwort von J. Dummer, Opuscula IX/1, Leipzig 1980, (591-629) 615. 
an important and at the same time a heavily disputed topic in ancient Christian theology, but still it is a partial problem, in "appropriate selection", and not the whole subject of Theology.

As has been said, the text is not a piece of protreptic promotional literature for a whole system of teachings or form of living. Nor is it an

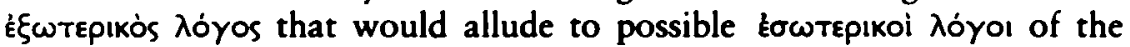
same topic in the background, which would - in accordance with Plato's idea - only be accessible to a particular circle in the special tradition of oral teaching ${ }^{29}$. Right at the end of the text, future topics and circum-

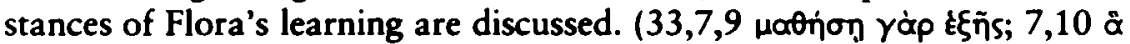

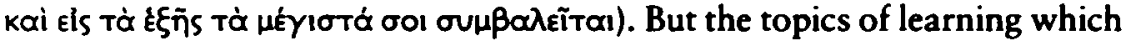

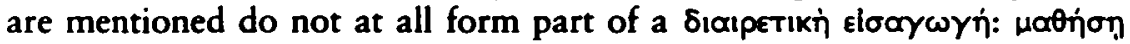

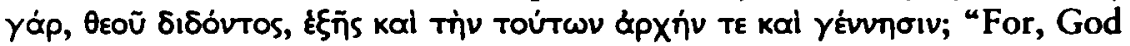
permitting, you will next learn about both, the first principle and the generation of these". With this concise phrase the author signals that at this point he breaks off his commentation on the three principles god father, demiurge and devil. He had presented them as parvóneva, but the

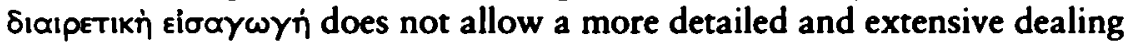
with first causes. And indeed: the seemingly short comments on the theory of principles in the last but one chapter of the Epistle meets the demands of the genre: in eisagogical treatises of this kind one should deal with Tà paıvónEva but not with tàs aitias ${ }^{30}$. The Greek phrase I cited is often said to be an introduction to gnostic esoteric doctrines, to Ptolemy's system: “it announces ... the introduction to his system of thought" ${ }^{31}$. However, the Greek phrase simply relates to the theory of three principles and first of all must be interpreted with regard to the genre of Ptolemy's text. But the elements Heikki Koskenniemi and Klaus Thraede described as intrinsic

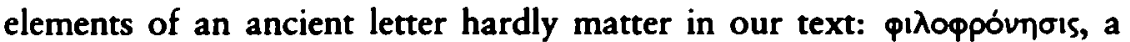
friendly fundamental attitude of the writing parties; mapouoia, the creating of a mental presence of absent dialogue partners; and finally $\delta \mu \lambda i \alpha$, the dialog-character of the correspondence ${ }^{32}$ only - if at all - shines through in the friendly remarks to Flora at the end of the letter $(33,7,8-10)$

29 For references and bibliography see K. Gaiser, Art. Exoterisch/Esoterisch, HWPh 2, Basel/Stuttgart 1972, 865f. - It was called an "exoterisches Lehrschreiben" by U. Kühneweg, Das neue Gesetz. Christus als Gesetzgeber und Gesetz. Studien zu den Anfängen christlicher Naturrechtslehre im 2. Jahrhundert, MThS 36, Marburg 1993, 89.

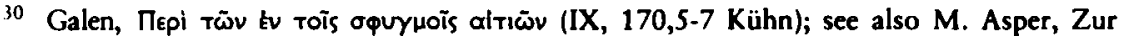
Struktur und Funktion eisagogischer Texte (see note 23), 311.

31 U. Kühneweg, Das neue Gesetz (see note 29), 93; for the interpretation as an "exoteric text" see also P. Lampe, Die stadtrömischen Christen in den ersten beiden Jahrhunderten. Untersuchungen zur Sozialgeschichte, WUNT 2. R. 18, 2nd rev. and suppl. ed., Tübingen $1989,255 f .326 f$.

32 H. Koskenniemi, Studien zur Idee und Phraseologie des griechischen Briefes bis 400 n.Chr., AASF Ser. B 102/2, Helsinki 1956, 35-53; K. Thraede, Grundzüge griechischrömischer Brieftopik, Zetemata 48, München 1970, 109-179. 
and in the kind address $\alpha \delta \varepsilon \lambda \Phi \eta \dot{~ \mu o u ~} k \alpha \lambda \eta \dot{\eta} \Phi \lambda \omega \dot{\omega} \alpha$ at the beginning of the corpus of the letter $(33,3,1)^{33}$. Peter Lampe's theory which says that Ptolemy treats the example of divorce as a focal point of the fourth chapter, because the addressee had split with her husband ${ }^{34}$, would identify a classical element of communication in private letters in the Epistle provided that his theory was right. But, as will be demonstrated in the second main chapter, his theory too readily combines observations on the text and pieces of information independent of the text handed down by Justin. Regarding the demands of ancient epistolography, one is bound to

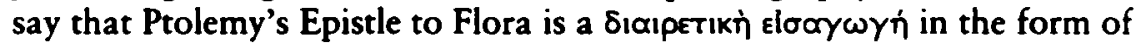
an epistle but not an epistle in the strict sense ${ }^{35}$.

After this first and more general step of regarding the genre of the text, we can now proceed to set out the structure of the Epistle: Ptolemy's Epistle to Flora can be structured as a tree with three main branches of

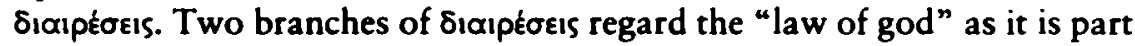
of Moses' Pentateuch: The law divides into the proper legislation of god, into the legislation of Moses and into the legislation of the elders (4,1-14). The proper legislation of god again can be divided into the pure legislation of god (the decalogue), into god's legislation interwoven with evil (the ius talionis) and into the typical or symbolical (the so-called "ritual law") $(5,1-6,6)$. A third sıaipeo's is expound in the paragraph that deals with the establisher of god's legislation $(7,1-7)$. God's law does not originate in the supreme god nor in his opponent the devil, but in the second, intermediate god, which is the demiurge. The author's skilfulness already shows in the fact that in both topics he works with a tripartite

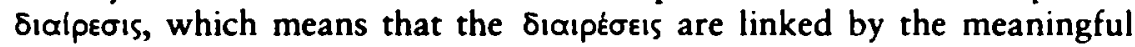
number three.

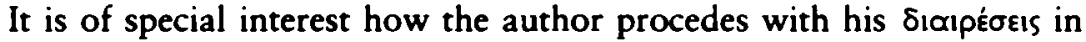
detail. In a first step, Ptolemy delimits the three parts of the law from each others - the law of god, the law of Moses and the law of the elders - in

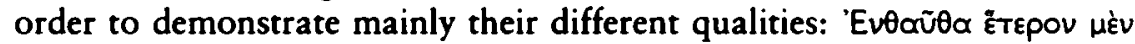

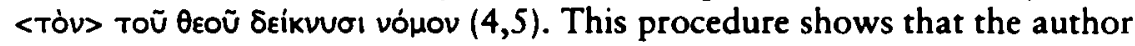
was acquainted with the philosophical techniques of his time and knew how to define terms: first the specific differences are named and then the differences or the different qualities of the specified terms are inferred. Ptolemy infers with certainty, which is, according to the standards of his

33 For the extended use of "sister" as form of salutation for a person "with close enough a relation" in pagan contexts as well, see also H. Koskenniemi, Studien (see note 32), 105.

34 P. Lampe, Die stadtrömischen Christen (see note 31), 202; different: A. Rütten, Der Brief des Ptolemäus an Flora (see note 11), 59.

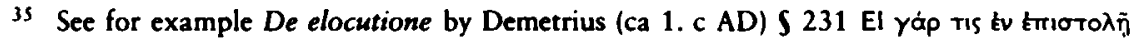

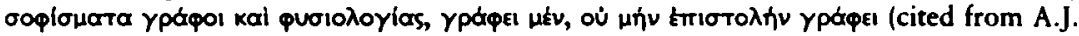
Malherbe, Ancient Epistolary Theorists, SBibSt 19, Atlanta, Georgia 1987, 17; see the thorough analysis by $K$. Thraede, Grundzüge [see note 32], 20f.25). 


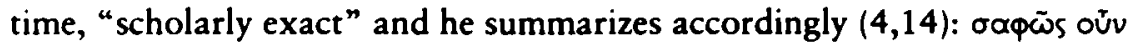

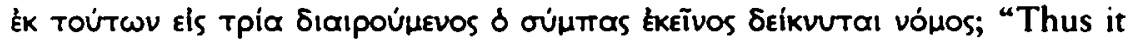
has been clearly shown from these passages that, as a whole, the law is divided into three parts." The following passages of the text are in accordance with the "dihaeretic" method as well: First the most interesting part of the whole legislation, the legislation of god himself, is further divided into three parts $(5,1-6,6)$. Then this is followed by the concluding dihaeresis of the three principles (7,1-7). The special order of the Dıaıpéreıs is clearly due to factual reasons. The selection of especially characteristic examples however is rather due to catechetical reasons. The latter aspect is pointed out by the author himself and has its origins in selection and

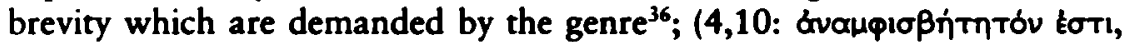

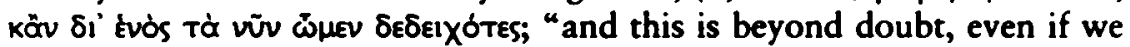
have for the moment used only one example").

So much for the genre of the text. We have seen that Ptolemy has

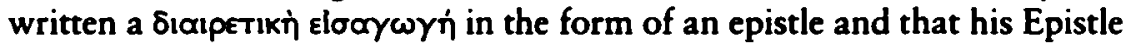
to Flora is only interpreted correctly, if one sees to the characteristics of the genre, which of course were administered brilliantly by the Roman teacher. On these grounds we can now turn to the theory of legislation and to the theory of principles as presented in the text.

\section{(Ib) The theory of legislation presented in the text}

In order to understand why and how the two Sıaıpéorıs of god's legislation and the closing סiaipeors of principles are connected, one must first realize against whom Ptolemy opposes in his Epistle. The author gives us a hint right at the beginning of his Epistle. The Elooywyn into the topic of legislation starts with the report of two positions on the law established by Moses which will be refuted in the following course of the text: Some say the law has been ordained by god the father, "while others, ..., stoutly contend that it has been established by the adversary, the pernicious devil" $(3,2)^{37}$. There is a large degree of agreement on the identification of the two groups holding these positions. The vast majority of interpreters ascribes the first position to the so-called Christian "main stream theology" of the city of Rome. Some identify it as the position of the "Catholics" within the framework of the dualism between Catholics and Gnostics suggested by Quispel ${ }^{38}$, or, following Harnack ${ }^{39}$, it is alternatively called

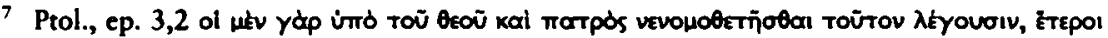

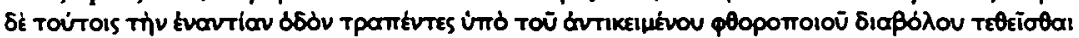
Toütov loxupicontal.

38 G. Quispel, Ptolémée, Lettre à Flora (see note 9), 76; U. Kühneweg, Das neue Gesetz (see note 29), 90 (quotation).

39 A.v. Harnack, Der Brief des Ptolemäus an die Flora (see note 28), 508-592. 
the Jewish position. The second position generally is ascribed to Marcion's followers ${ }^{40}$. But Ptolemy certainly simplifies both positions for didactic reasons here. He gives an ideal-type reconstruction of two positions which both were, from his point of view, equally absurd ${ }^{41}$. To give one instance of his simplifications: A follower of Marcion would have assigned the law with its principles of reward and punishment to the second, restricted creator-god and his cruel hardness, but not right away to the devil ${ }^{42}$. But the stylized report at the beginning of the Epistle at the same time shows that in the middle of the second century everybody who theologically worked on Old Testament legislation was bound to deal with the establisher of the law as well. Theory of principles and theory of legislation were closely connected.

At the same time the stylized report of the two positions signals that Ptolemy intends to treat the topic of "legislation" not like the Marcionists against the background of the theory of the two principles "god" and "devil", but against the background of a theory of three principles. And one can foresee that the solution to the problem lies "in the middle": Neither god the father nor "the adversary, the pernicious devil" are authors of god's law in the Pentateuch, but - as Ptolemy says in the seventh chapter - "the craftsman and maker of the universe or world"

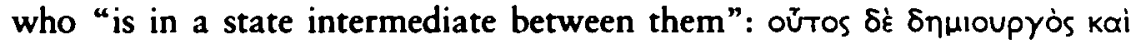

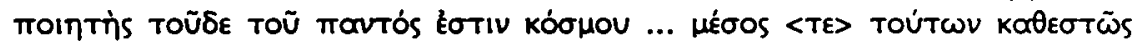
$(7,4)$.

It is interesting to see that both passages, the introductory alternative of two absurd and wrong positions in the third chapter $(3,2)$ and the solution of the problem at the end of the digression in the seventh chapter $(7,4)$, are connected by the same reference to Plato, which is alluded to twice. This is a skilful literary figure, used in order to draw the readers' attention to the ring-composition. "The adversary, the pernicious devil" is further described as the one who is "according to them... the father and

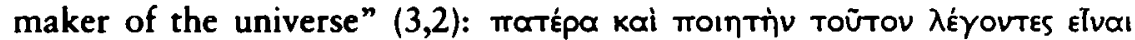

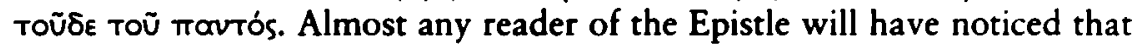
this was an allusion to Plato's Timaeus 28c, because this was - I cite Henry Chadwick - one of the "hackneyed quotations of Plato in the

40 U. Kühneweg, Das neue Gesetz (see note 29), 90 (quotation); see G. Quispel, Ptolémée (see note 9), 76; H. Freiherr von Campenhausen, Die Entstehung der christlichen Bibel, BHTh 39, Tübingen 1968, 99; G. Lüdemann, Zur Geschichte des ältesten Christentums in Rom (see note 18), 1064.

41 If W.A. Löhr, Die Auslegung des Gesetzes bei Markion (see note 10), 80, means by his statement that Ptolemy doxographically confronted two positions and suggested that the solution lies in the middle of the two - what I described with the help of the expression "ideal-type", we both interprete the passage in the same sense.

42 For the second god see E. Mühlenberg, Marcion's Jealous God, in: Disciplina Nostra. Essays in Memory of Robert F. Evans, ed. by D.F. Winslow, PatMS 6, Philadelphia 1979, 93-113. 


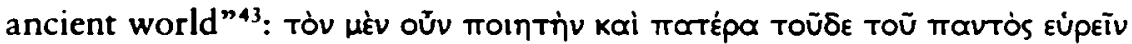
$T \varepsilon$ Épyov. In the final chapter of the Epistle, where the true author of the law of god is introduced, the same verse taken from Plato is alluded to,

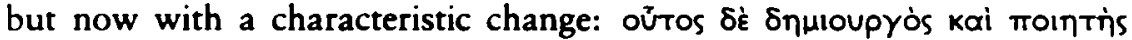

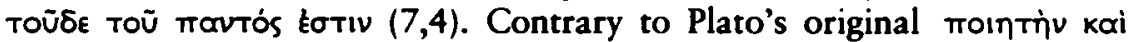
Tortép and its first comparatively simple modification in the third chapter

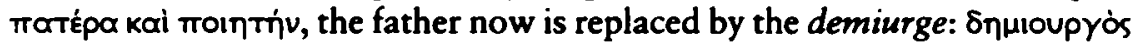
kai mointris. When studying the interpretations of Plato's phrase in

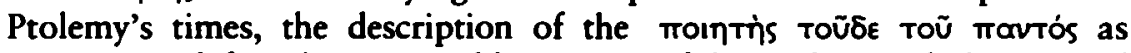
¿nuroupyós definitely is a possible exegesis of this widespread phrase. And besides, this exegesis could refer to the mention of the inuloupyós oryatós in the immediate context (Tim. 29a; cf. also Tim. 28a, 31a, 41a and $69 c)^{44}$.

So the attentive reader notices right at the beginning of the digressions on the law that the two topics of the theory of principles and the theory of legislation are closely connected and thus that the text is a careful ringcomposition and not at all in the last chapter an attempt of "clearing the bar" from down the exoteric depths of the plain up to a faintly hinted at distant plateau of esoteric doctrines. We now turn to the topic of legislation in its proper sense and conclude this section by raising the question whether the specific solution of two bıaıpkoeıs of the law of the Pentateuch can be positioned more precisely within the framework of a Christian history of theology of the ancient world. This point has not been treated sufficiently neither by earlier works nor by studies of recent years.

In order to position Ptolemy's view on the Old Testament law correctly in the history of Christian Theology, we are now going to distinguish between traditional and original elements of his view. First of all it is clear that Ptolemy's first tripartition of the law - the tripartition into the law of god himself, the legislation of Moses and finally the legislation of the elders at the beginning of the fourth chapter ${ }^{45}$ - works with and synthesizes established ideas of his time. Parallels in Jewish-Hellenistic or rabbinical literature can be found for each name of the three parts of the law.

43 H. Chadwick, Origen Contra Celsum, Cambridge 1965, 429; for bibliography see Ch. Markschies, Platons König oder Vater Jesu Christi? Drei Beispiele für die Rezeption eines griechischen Gottesepithetons bei den Christen in den ersten drei Jahrhunderten und deren Vorgeschichte, in: Königsherrschaft Gottes und himmlischer Kult im Judentum, Urchristentum und in der hellenistischen Welt, ed. by M. Hengel and A.M. Schwemer, WUNT 55, Tübingen 1991, (385-439) 401 note 76.

44 H. Dörrieł/M. Baltes, Die philosophische Lehre des Platonismus. Platonische Physik (im antiken Verständnis) II Bausteine, 125-150: Text, Übersetzung, Kommentar. Der Platonismus in der Antike. Grundlagen - System - Entwicklung Bd. S, Stuttgart-Bad Cannstatt 1998, 262-329.

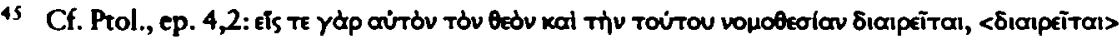

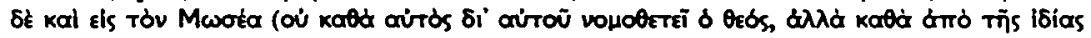

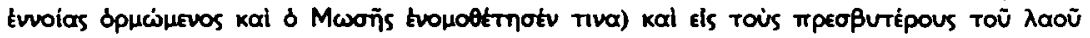

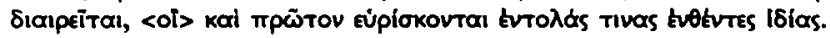


The "legislation of the elders" $(4,2)$ or the phrase commandments of the

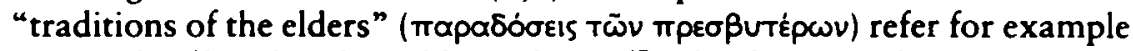
to Josephus ${ }^{46}$ and early Rabbinical texts ${ }^{47}$. The division of a pure legislation and an impure legislation interwoven with evil in the second "dihaeresis" is not original, either. Quispel in his commentary ${ }^{48}$ already had pointed to a to some degree comparable concept in the so-called "Kerygmata Petrou" of the Pseudo-Clementine Homilies, where the idea is presented that after Moses had given the law to the seventy elected (Num $11,24)$, the law was set down in a very short time, in the course of which "a number of wrong pericopes found its way into it. And there the only god is calumniated ... The Evil dared to do so with good reason ${ }^{\text {49 }}$. So, according to this Jewish-Christian theology of legislation, it was through the devil that parts of the Mischna found their ways into the law and have, being imperfect themselves, distorted the law. Of course, as we have said, this position can only be compared to some degree, for as precisely as Ptolemy identifies the "pure law" with the decalogue, as precisely does he identify the "impure law" with the ius talionis $(5,4)$. Of course, roots of Ptolemy's division of the decalogue and the rest of god's legislation $(5,3)^{50}$ can be found in the Judaism of his time ${ }^{51}$. But those divisions do not imply that commandments which are not part of the decalogue are valued less ${ }^{52}$. There also is a longer Jewish tradition of the symbolic interpretation of legislation on the "sacrifice, circumcision, Sabbath, fasting, Passover, unleavened and the like". In Barnabas' Epistle, in Justin and in Irenaeus, the interpretation of these commandments which standardize the exclusively Jewish ethos and which we - usually anachronistically and incor-

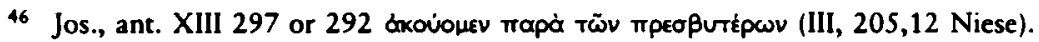

47 bShab 31a; Abot 1,1 and 3,14; Sanh 11,3 and jBer 1,3b [47]; bEr 13a. 21b; Tan Naso 29 (cf. BamR 14 to 7,48 (p. $58 b=116$ ): צות זקנים רכרי נים, "the words of the elders" or "the commandments of the elders"; for further Rabbinic parallels see S.T. Lachs, A Rabbinic Commentary on the New Testament. The Gospels of Matthew, Mark, and Luke, Hoboken, New Jersey/New York 1987, 245.247; for general information also J. Neusner, Die pharisäischen rechtlichen Uberlieferungen, in: id., Das pharisäische und talmudische Judentum, TSAJ 4, Tübingen 1984, 43-51 and id., Geschichte und rituelle Reinheit im Judentum des 1. Jahrhunderts n.Chr., ibid., 74-88.

48 G. Quispel, Ptolémée, Lettre à Flora (see note 9), 87.

49 Ps.-Clem., hom. II 38,1/2 (GCS Pseudoklementinen 51,1-13 = W. Schneemelcher, NTApo II, Tübingen ' 1997,482 ); see also hom. III 47,1 and 50,2 and G. Strecker, Das Judenchristentum in den Pseudoklementinen, TU 70, Berlin ${ }^{2} 1981,151-153$.

so See EpArist. 128-143 and Philo, migr. Abr. 89-93 (II, 285,25-23 Wendland).

si Ps.-Philo, Liber antiquitatum biblicarum 11-13; Josephus, ant. III 89f.; see also Const. App. I 6,10 (SC 320, 118, 24-26 Metzger) and II 5,6 (152,20-22) and the Syrian Didascalia 2 and 26 (TU.NF 10/2, 6,9-14 and 134,7-10 Achelis/Flemming) and E. Reinmuth, Beobachtungen zum Verständnis des Gesetzes im Liber Antiquitatum Biblicarum (Ps.-Philo), JSJ 20, 1989, 151-170. - I thank my New Testament colleagues K.-W. Niebuhr (Jena) and M. Wolter (Bonn) for their useful comments.

52 This is clearly pointed out by E. Reinmuth, Beobachtungen zum Verständnis des Gesetzes, 163-165. 
rectly - call "ritual law", must be seen against the background of the discussion with Judaism ${ }^{53}$.

It is difficult to compare Ptolemy's position with other theories of

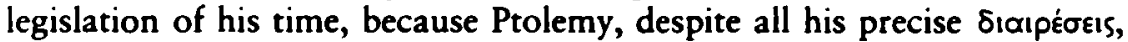
remains very unprecise in one point in his second distinction - which, to my opinion, is a sign of his "theology in the making": the law interwoven with evil, that is the ius talionis, is incongruous with the nature of the saviour, and therefore the saviour abolishes it $(5,1)$. And because of its abstract justice of retaliation "it is incongruous with the nature and goodness of the father of the entirety" $(5,5)$. It must be noted that Ptolemy, without giving any explanation, adds considerations to his consistent theory of the ius talionis which are of the same sort as Origen's occasionally presented in his works: Ptolemy asks whether it could not be possible that even the ius talionis, which is so problematic in its interweaving of good and evil elements, was congruous with the father's nature and loving-kindness. But then he draws back to the position that at any rate the ius talionis would be necessary $(5,6)^{54}$, something which admittedly he had said before indirectly when he had pointed to the positive function of the ius talionis for peace under a society's law $(5,4 \mathrm{f}$.). By the way, here again it shows indirectly that the true systematic interlocutor of Ptolemy was Marcion - for, as we all know, Marcion completely rejected the ius talionisss.

I conclude: Even if Ptolemy's terminology as well as the elements of his two haeresis originated in the Jewish and Christian discussions of his time, I suggest that the solution goes back to Ptolemy himself. This most clearly shows in its construction: especially the first siaipeois demonstrates that Ptolemy, with an Anti-Marcionite emphasis, combines observations on the biblical text with a philosophical elementary dissociation in a very original way. The author explains his tripartite division into god's own

3 F.F. Fallon, The Law in Philo and Ptolemy: A Note on the Letter to Flora, VigChr 30, 1976, (45-51) 49; T. Stylianopoulos, Justin Martyr and the Mosaic Law, SBL Dissertation Series 20, Missoula/Montana 1975, 45-76; U. Kühneweg, Das neue Gesetz (see note 29), 253-255. - For the comparison with Melito of Sardis see B. Lohse, Meliton von Sardes und der Brief des Ptolemäus an Flora, in: Der Ruf Jesu und die Antwort der Gemeinde. Exegetische Untersuchungen Joachim Jeremias zum 70. Geburtstag gewidmet von seinen Schülern, ed. by E. Lohse, Göttingen 1970, (179-188) 181. T. Stylianopoulos, Justin Martyr and the Mosaic Law, 55 note 27, draws the attention to the large differences in the threefold dihaeresis of the law between Justin and Ptolemy; Quispel assumes identical concepts (id., Ptolémée, Lettre à Flora, 23).

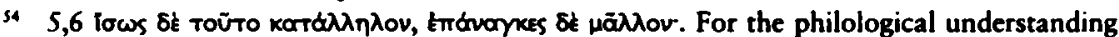
of the sentence see W.A. Löhr, Die Auslegung des Gesetzes (see note 10), 81 note 17 (different G. Quispel, Ptolémée, Lettre à Flora [see note 9], 63).

ss For references see G. Quispel, Ptolémée, Lettre à Flora (see note 9), 92: Adamantius, dial. $814 \mathrm{a} / \mathrm{b}$ (GCS Adamantius, 32,7-13 van de Sande Bakhuyzen) and of course A.v. Harnack, Marcion. Das Evangelium vom fremden Gott. Eine Monographie zur Geschichte der Grundlegung der katholischen Kirche. Neue Studien zu Marcion, TU 45 and 44/4, Darmstadt 1985 (= Leipzig ‘1924/1923), 106-118.90/280*. 
law, the law established by Moses and the law established by the elders, in a twofold way: first with Matthew's account of the abolishment of divorce, which had been permitted by Moses (4,3-10; cf. Mt 19,6-8). And then with the corban-practice established by the elders $(4,11-14)^{56}$. Especially the latter with its not very detailed text takes it for granted that the readers of the Epistle knew the Bible and Jewish-Christian customs very well ${ }^{57}$. But the first tripartite dissociation is explained additionally in a very original way with the help of the elementary philosophical terms karto mpoaiperiv and kará óvóyknv"s. According to Ptolemy, Moses ordained his law "based upon his own thoughts about the matter" 14,2 dito tins

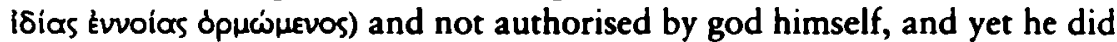
not ordain it out of his own inclination (kortà mpoaipeolv), but out of necessity (korà óvór $k \eta v$ ), "because of the weakness of those it was ordained to" $(4,6)$. The second biaipeors again uses the opposite terms kortò

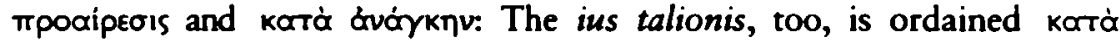
óvóyknu; Ptolemy goes even further by saying that he who ordained it "has without realizing it been cheated by necessity" $(5,6)^{59}$.

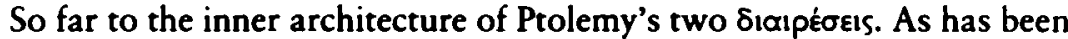
shown, he connects wide spread conceptions of divisions of the Old Testament legislation and comes out with an original - but not yet completely matured - solution. He justifies his argumentation with the biblical texts and develops it by means of a commonly known philosophical distinction. But it must also be noted that Ptolemy's specific solution to distinguish the law established by god himself and the law established by Moses based upon his own thoughts about the matter and upon necessity, clearly differs from Jewish-Hellenistic versions - it differs very basically in structure, because of the negative characterization of Moses. Both, Philo and Josephus, do not distinguish between god's legislation and Mose's legislation, but between god's legislation ordained by Moses and the commandments of the presbyters ${ }^{60}$. So they only know a division of the normative rules into two parts and not a tripartite system as presented by Ptolemy. Models for Ptolemy's solution could be found in the respective Jewish conceptions of a $\delta$ Eutépwors of God's law, mainly found in Epiphanius. The $\delta \varepsilon u t \varepsilon p \omega \sigma i s$ of Moses also is mentioned there. But even the latter

56 See M. Schlusser, The Corban Passages in Patristic Exegesis, in: T. Halton/J. Williman (Eds.), Diakonia (Studies in Honor of Robert T. Meyer), Washington 1986, 101-107.

s) Thus it is more than an anecdote when I tell the story of the course I gave on the text together with my colleague from the Classics Department, Juergen Dummer, at Jena in 1998, where those participants of the course studying Classics did not understand the argumentation of the corban-vow at all.

s8 W.A. Löhr, Die Auslegung des Gesetzes (see note 10), 83 to my opinion correctly states that in the background a reflection on god's freedom could be assumed.

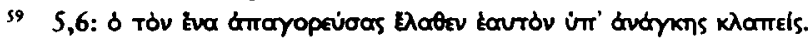

so The careful linguistic distinction of uores and tvroגal shows the thematic differentiation even in places where it is not explicitly mentioned. 


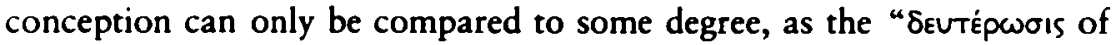
Moses" precisely means the Old Testament book Deuteronomy. This observation again verifies the original character of Ptolemy's conception ${ }^{61}$.

I have already briefly mentioned the theory of principles of the Epistle. It remains to take a more detailed look at this difficult topic.

\section{(Ic) The theory of principles presented in the Epistle}

It has already been shown that the remarks briefly mentioned on the theory of principles presented in the opening and the ending of the text must be interpreted in the context of the literary genre of the Epistle. It further has been said that Ptolemy had prepared his solution mentioned

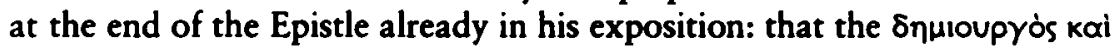

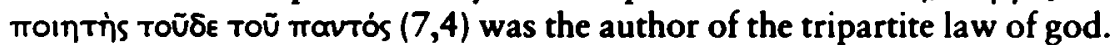
If one takes the ring-composition seriously, a theory evolves that includes three principles: the perfect god and father as the supreme principle $(3,4$ :

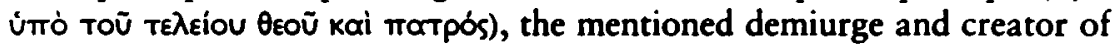
the universe and finally the "adversary, the pernicious devil" $(3,2)$. When assuming that Ptolemy held such a theory of three principles, the text can easily be understood for the moment. This is also the best way of understanding the relation between the explanations on the law and those on the principles - furthermore, we have already considered the unified model of a staipeors which always leads to three principles. But several times there is a fourth figure mentioned in the text: the $\sigma \omega$ trip. Therefore, one of the key questions of the interpretation of our text is, whether this fourth figure can be integrated into Ptolemy's theory of three principles described just now. Or, must it rather be taken as a clear hint for a far more complex system of the theory of principles, which could either be reconstructed in the light of the different Valentinian systems, or be understood as one of these systems in an earlier stage? With regard to the aim of our investigation, we must confine ourselves to observations on the owrnip. It is astonishing that Winrich Löhr does not discuss this problem at all in his excellent work on the "doctrine de dieu" in Ptolemy's Epistle to Flora ${ }^{62}$,

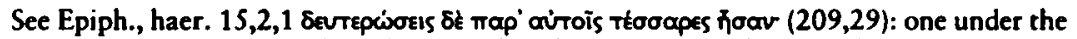
name of Moses, the prophet, the second under the Name of the teacher Aqiba or Bar Aqiba, another under the name of Addan or Annan, also called Judas, and another under the name of the sons of Asamonaios (= Hasmoneus). For explanations see the interpretation by Emil Schürer (Geschichte des jüdischen Volkes im Zeitalter Jesu Christi I, Leipzig ${ }^{34} 1901,122$ note 24): 'Unter der 'Deuterose des Moses' ist das Deuteronomium zu verstehen, unter der 'Mischna der Hasmonäer' vermuthlich die Anordnungen des Johannes Hyrkanus, welcher die pharisäischen Satzungen beseitigte und dadurch ein neues Recht schuf. Ein Codex dieses hasmonäischen Rechtes wird, wie es scheint, Megillath Taanith S 10 erwähnt; vgl. hierzu Derenbourg, Histoire de la Palestine p. 103".

62 However, having read his paper, one could assume that he favours a theory of four principles: W.A. Löhr, La doctrine de dieu (see note 10), 188: "Le Révélateur, c'est le fils monogène du premier Dieun". 
although it were mainly his expositions on form and translation of the text that prepared the grounds for the solution presented in the following.

The meaning of the term owtrip is not explained in the Epistle to Flora, which means, it is taken for granted that the reader of the Epistle knows the term. The term is almost exclusively used in connection with citations from the New Testament that are introduced as $\lambda \dot{\gamma} \gamma$ ol of the $\sigma \omega$ Trip (nine times:

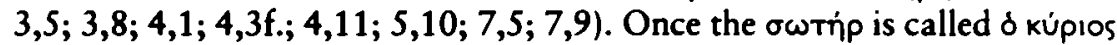
$(4,4)$. Finally, alluding to $\mathrm{Mt} 5,17$, he is said not to have come in order to abolish but to fulfill the pure law as it is presented in the decalogue $(5,1 ; \mathrm{cf}$. $6,1)^{63}$. But he is said to have abolished the ius talionis (dito; cf. 6,2) and to have changed the commandments which are nowadays anachronistically called "ritual law" from the perceptible level to the spiritual, invisible one $(5,2)$. I only mention in passing that Ptolemy obviously sees the fulfilment of the decalogue in its completion by the commandment of love for enemies (cf. 5,5 and 6,3). In our context it is more interesting to see that $\sigma \omega$ Trip obviously is meant as a title for Jesus while he was on earth. It is he who, following the New Testament, speaks all the words beginning with the formula mentioned when cited by Ptolemy and it is he who is said to have abolished, fulfilled and re-interpreted the law. All the same, never in the whole Epistle is he called Jesus or Christ ${ }^{64}$. This is a surprising observation and I have not found a proper explanation for the phenomenon yet: The identity of Jesus and the $\sigma \omega \boldsymbol{T r}_{\mathrm{p}}$ is more than obvious for any unbiased reader and yet this identity is not made explicit in the text.

The key question of the relation between Jesus dwelling on earth, called

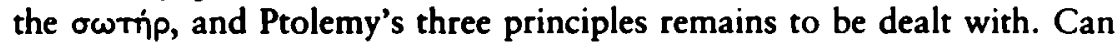
the $\sigma \omega$ Trip be identified with one of the three or is he meant as a fourth principle? A sentence in the third chapter can be taken as a first hint. It paraphrases a verse of the prologue of the Gospel according to John $(3,6)$ :

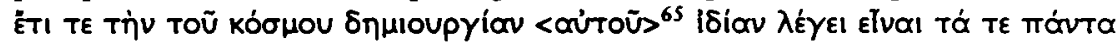

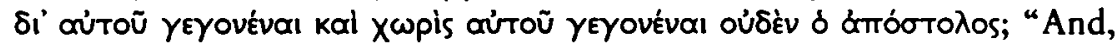
further, the apostle states that the craftsmanship of the world is his and that 'all things were made through him, and without him was not anything made' (Joh 1,3$)^{n}$. The context of the phrase philologically leaves no doubt that the "creator of the universe" is identical with the owtrip. This grammatically definite connection of the demiurge and the owTin comes as such a surprise for many interpreters that at this point they suddenly

63 A.v. Harnack, Geschichte eines programmatischen Worts Jesu (Matth. 5,17) in der ältesten Kirche, SPAW.PH 1912, (184-207) 194f. = id., Kleine Schriften zur Alten Kirche, Bd. 2 Berliner Akademieschriften 1908-1930, with a foreword ed. by J. Dummer, Opuscula IX/2, Leipzig 1980, (166-189) $176 f$.

ot The term "Christ" appears only once in the quotation: ep. Flor. 5,25 (= 1Cor 5,7).

6s I do not intend to give detailed reasons here for my assumption that Holl's insertion of the <ourroũ is not necessary and that the text must be understood in the sense given without this conjecture as well. See for example W.A. Löhr, La doctrine de dieu (see note 10), 181. 
change the course of their interpretation. Lüdemann for example believes that the $\sigma \omega$ trip was only called "creator" in a figurative sense and that the demiurge - not identical with the saviour - was the "creator". But such a differentiation is neither expressed nor indicated in any way ${ }^{66}$. Quispel gives a report of the Valentinian myth and concludes: "Ainsi la création du monde est l'oeuvre du Christ et de lahvé ${ }^{-67}$. Unfortunately, this is not at all expressed in the text. On the contrary: it can be assumed - if the wordings do not have a secret parallel sense - that the citation of John does not only indicate the identity of the demiurge and the $\sigma \omega t$ trip (saviour), but also the identity of the $\lambda$ byos with these two. The differentiations of the Johannine tá TE Távta found with other Valentinians, do not seem to matter here ${ }^{68}$. This seemingly surprising interpretation proves

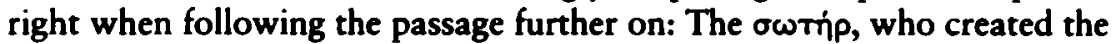
universe, is then described as a "just god who hates evil" (3,6: $\measuredangle \lambda \lambda \dot{\alpha}$

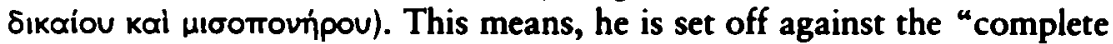
god and father" to whom 'goodness' is attributed. Thus the soter-demiurge is a god of second order. He is the "god of righteousness" $(3,7)$ and subdued to necessity $(5,6 \mathrm{f}$.), while, contrary to him, the supreme god and father, "god alone" $(4,1)$ and "god himself" is thought of as free per se.

The most important sentence of the whole text regarding the "theory of principles" is written in the final seventh chapter. It states on the

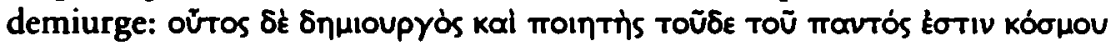

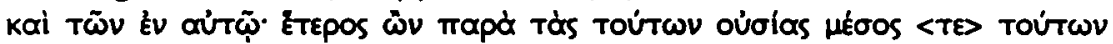

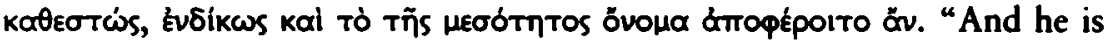
the craftsman and maker of the universe or world and of the things within it. Since he is different from the essences of the other two <and> (rather) is in a state intermediate between them, he would rightfully be described

G. Lüdemann, Zur Geschichte des ältesten Christentums in Rom (see note 17), 109 note 73: "Ebenso wie der Pentateuch als Gesetz Gottes bezeichnet werden konnte und gleichwohl ein anderer, der Demiurg, sein unmittelbarer Geber ist, so ist nach Ptolemäus die Schöpfung die des Soter, doch gleichwohl der Derniurg der unmittelbare Schöpfer". The argument is not convincing: The Pentateuch can be named "law of god", because the demiurge is understood as a god and is even called so twice in important places: 3,7 io

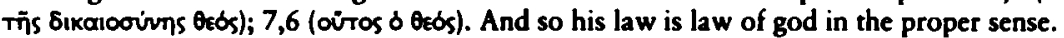

67 G. Quispel, Prolémée, Lettre à Flora (see note 9), 78. - W.A. Löhr (La doctrine de dieu [see note 10], 180-182) corrects the mistranslation, but he does not draw conclusions out of his correct translation for the theory of principles.

68 Some Valentinians clearly differentiate the interpretation of Joh 1,3: According to Origen, Herakleon (frgm. 1 = Or., comm. in lo. II 14,100 [GCS Origenes IV, 70,3-71,11 Preuschen]) only refers To $T E \pi d v T \alpha$ to the kóouos and says: "Not the eon, nor what is in the eon, has come into being through the logos"; contrary to this, Irenaeus presents a Valentinian interpretation (haer. III 11,1 [SC 211, 140,14-17 Rousseau/Doutreleau]), which does not relate $\tau d \alpha \pi$ Tavta to the kosmos, but only to ea, quae sunt infra Pleroma ipsorum (...), which is, to the world of eons. The Valentinian interpretation in exc. Thdot. 45,3 (GCS Clemens Alexandrinus III, 121,10-12 Stählin/Früchtel/Treu) presumably represents a third type: "And so, because of the appearance of the saviour, the Sophia is created without passions and outside (the Pleroma). Because 'all is through him..."”. 
by the term intermediateness" $(7,4)$. To my opinion, this crucial sentence indicates Ptolemy's true systematic achievement. It contains the main point of his theory of principles - of course only in the form of allusion according to the demands of the genre of the text. The second god is positioned 'in the middle' between the supreme god and father and the devil. So Ptolemy applies the distinction of "good", "evil" and "in the middle of the two"69, known from the ethics of Middle-Platonism and going back to Aristotle, to his theory of principles.

This main point in Ptolemy's theory of principles of course provokes the question, whether more instances of this ethical contrast applied to the theory of principles can be found in philosophical texts of Ptolemy's time, or whether it must be regarded as an utterly original achievement of the Roman teacher Ptolemy. I have only found one example so far that shows that Ptolemy's systematic solution takes up terms and ideas that were discussed in certain peripheral fields of the Platonism of his days. One rightly asks whether they influenced Ptolemy directly, or whether his solution even was 'in the air' at his times. In Plutarch's treatise on Isis and Osiris it is said that most and the wisest people believed the existence of two contrasting gods, one of them the craftsman ( $\delta \eta \mu$ roupyós) of good and the other one the craftsman of evil ${ }^{70}$. Some would only call the previous one 'god' and the latter a demon; Zoroaster would call one of them Oromazes and the other one Areimanius, but they both would best be

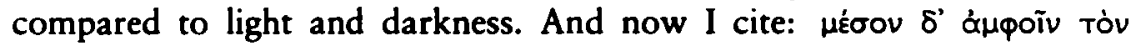

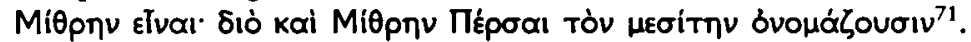

Unfortunately, the last paragraph of the Epistle to Flora does not give, for reasons of genre, more than suggestions, and one phrase is hardly understandable and presumably grammatically corrupt $(7,7 b)-$ a problem we cannot discuss now. Most of all the figure of god - which interests

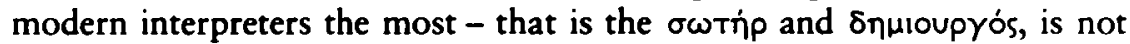
very clear-cut in Ptolemy's Epistle. But whereas the contrast between the supreme father-god and the devil is impressively described by attributes ${ }^{72}$, the figure in the middle remains rather vague. We are only told that, being engendered, he is not complete in the same way as the supreme god and father, but that he is of incomplete, inferior divinity and thus of incomplete and minor righteousness $(7,5 \mathrm{f}$.).

69 See i.e. Alkinoos, did. 5 (p. 156,41f. Hobein = CUFr 9 Whittaker): toùs $u \dot{k} v$ dyatoùs elvar, toùs $\delta \dot{k}$ korooús, toùs $\delta \dot{k}$ uḱoous, Commentary by J. Dillon, Alcinous. The Handbook of Platonism, Oxford 1993, 73f.

to Plut., Is. S 46 (369 D [BiTeu II, 46,6-10 Sieveking]).

7 Plut., Is. S $46(369 \mathrm{E}[46,14-16])$. In $\int 48(370 \mathrm{C}[48,4])$, Plutarch mentions three Chaldaeic middle-gods, ibd. (370 F $[49,10 f]$.$) , three souls which, according to Plato,$

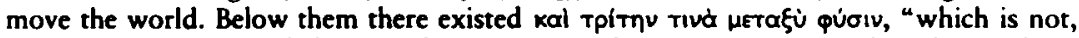
contrary to what some believe, without reason and its own movement, but akin to those two, but still always clings to and strives after the better one".

72 See the following chart (referring to 7,7 ): 
The interpretation of the Epistle to Flora I am presenting seems to be, at first glance, a complete break with the history of interpretation of our text, because Ptolemy's theory of principles is dissociated from the theory of other Valentinian systems. There can hardly be anything more contrasting to the Valentinian system than the identification of demiurge and $\sigma \omega T r p^{73}$. But in fact there are scholars who interpreted the Epistle in a similar way, for example, thirty years ago, Bernhard Lohse ${ }^{74}$. Besides, it should not be forgotten that, in the light of our access via the literary genre, we interpreted the relevant passages only as brief remarks on the theory of principles. One simply cannot tell from the remarks in the Epistle to Flora how closely demiurge and $\sigma \omega T$ rip were linked, whether they were regarded as two modes of existence of the same thing or strictly as identities. The observation that the names Jesus or Christ are avoided in the Epistle suggests that Ptolemy to some degree did distinguish certain "modes of existence" of his second god. In addition one must realize that the strict alternative of identity and difference falls too short here. The Valentinian system explained here distinguishes divine figures by means of thoroughly elaborated dialectics on the one hand and on the other hand relates them again by their names. The different names used by Irenaeus

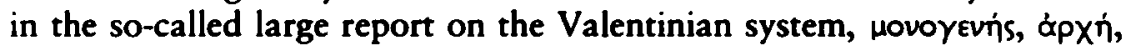

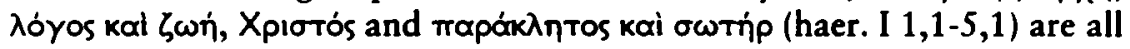
applied to the one figure Jesus Christ in the canonical New Testament and presumably the Valentinians did not use them as names for completely distinct identities in the strict sense, contrary to what the ancient haeresiologists maintain. Mark Edwards was right when he pointed out recently that in the Platonist as well as in the Valentinian myth, persons

\begin{tabular}{|l|l|l|l|}
\hline Ousia ("essence") & God and father & soter-demiurge & devil \\
\hline incorruptibility & Incorruptibility & $?$ & corruption \\
\hline $\begin{array}{l}\text { immaterial/ } \\
\text { material }\end{array}$ & Selfexistent, simple & $?$ & darkness \\
\hline oneness/ dividedness & simple, unique & $?$ & material \\
\hline metaphor of light & Light & $?$ & divided into many parts \\
\hline & & (engendered) power & (engendered) power \\
\hline idea/ image & (better idea) & image of the better & (loss of being image) \\
\hline
\end{tabular}

73 Thus Hans-Martin Schenke's wording. I thank him and the whole "Berliner Arbeitskreis" that I had the opportunity of presenting and discussing my interpretations several times during my stay at the Wissenschaftskolleg/Institute for Advanced Study in Berlin (1998/

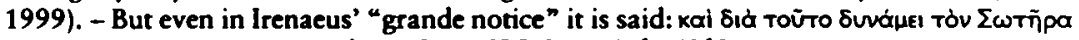

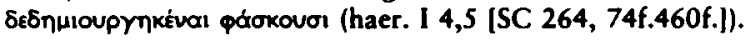

74 B. Lohse, Meliton von Sardes und der Brief des Ptolemäus an Flora (see note 53), 185; see also L. Diestel, Geschichte des Alten Testaments in der christlichen Kirche, Jena 1869, 67: "Bemerkenswerth ist es, dass in die ganze Deduction nichts von kosmischem Dualismus hineinblickt". 
or figures are differenciated, which, in reality, are aspects of one and the same thing ${ }^{75}$.

But how did Ptolemy's contemporaries judge this original and special theory of principles? Platonists would not have been much surprised by the strict separating of the completeness of the supreme god and the incompleteness of the second god - if they managed to get through the passages on the Old Testament law at all, which supposedly were not of great interest to them, and reached the remarks on the theory of principles near the end of the letter; Winrich Löhr already pointed to parallets in the theory of principles of Numenius and in the Commentary on Timaeus by Porphyry ${ }^{76}$. But still, maybe they were a little taken by surprise that the second god was defined as intermediate between god and the devil, although, according to his divine attributes and deeds of salvation, he was rather close to the father. Such an inconsistency could have reinforced a proper Platonist in his sceptical estimation of the intellectual abilities of Christian theologians. And Christian readers were likely to be very astonished because of the strict distinction made between the supreme god and father, and the demiurge and craftsman: for Ptolemy does not only

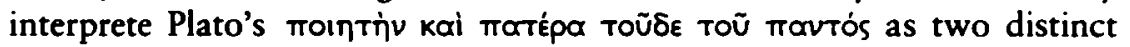
figures, but also uses the term mointins exclusively on the son, the $\sigma \omega$ Trip , the demiurge. And indeed, regarding the confession of the established

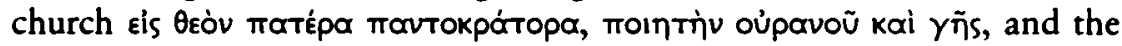
common use of the word $\pi 01 \eta \pi r^{77}$, this must be called a massive theological shift of emphasis ${ }^{78}$.

Where can Ptolemy's theory of three principles presented in his Epistle be positioned in the second century history of Christian theology? It is evident that, with its passages of slight inconsistency, one could say it goes with the general character of Christian theology at that time, which could be, as we have said, characterized as "theology in the making". Further, it is evident that Ptolemy took a very important step towards a gnostic theory of god and its differentiation of divine figures, when he regarded only the soter-demiurge as creator. And finally it is clear that a theory of principles developped against a Middle-Platonic background must have meant developing a system of strict subordination and that in so far,

is See Mark Edward's paper "Pauline Platonism: The Myth of Valentinus", also presented as master theme at the $13^{\text {th }}$ International Conference in Oxford 1999.

76 See the comments in W.A. Löhr, La doctrine de dieu (see note 10), 186: Numenius, frgm. 13 (CUFr 55,6f. Des Places); Porphyrius, frgm. 40 in Plat., Tim. 28 c (26,15-18 Sodano = Procl., in Tim. 91 F [BiTeu I, 300,1-6 Diehl]) and Ps.-Justin, Cohortatio ad Graecos 22,4 with the commentary in Ch. Riedweg, Ps.-Justin (Markell of Ankyra?), Ad Graecos de vera religione (bisher "Cohortatio ad Graecos"), SBAW 25/2, Basel 1994, $395 f$.

7 G.W.H. Lampe, PGL, Oxford 1961, s.v. with C. only documents a comparable reference from the Acta Phil. 73 (AAA IV/2, 29,9 Lipsius/Bonnet), where Christ is labeled as \& oúporvoũ kal rĩs moınTris. - Of course, this point demands further investigations.

78 This was already noticed by W.A. Löhr, La doctrine de dieu (see note 10), 185. 
Ptolemy went with a broad stream of trinitarian theological thinking in the early church. This even was expressed in the Epistle by a phrase which was to become the heavily disputed programmatic formula of the

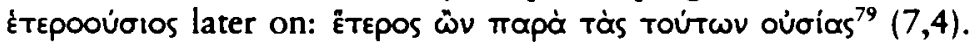

This interpretation of the development is not the common opinion of all interpreters of the Epistle to Flora, either. A little while ago, Uwe Kühneweg stated in view of a traditional interpretation of Ptolemy's theory of principles that Justin, with his conception of one single logos as a "second god" (dial. 56,11), in a way completed Ptolemy's thinking ${ }^{80}$. This means, Kühneweg reconstructed a systematic movement from Ptolemy's multitude of the figures of the sophia, of the demiurge and of the

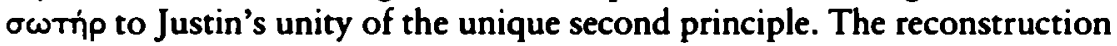
of a development from Ptolemy to Justin is historically problematic. Conversely, we now must put the question, whether Ptolemy and Justin did not still have the same conception of a simple theory of three principles and whether it was not only the generation of their pupils who introduced further dihaeresis into the conception or who intensified existing dihaeresis, surely because they were aiming at increasing the systematic complexity of the theory of principles that had been handed down to them. I think - without setting out my theory in full now - an interpretation of classical Valentinian gnosticism as we find it for example in Irenaeus' so-called "grande notice" has succeeded only when the high theoretical standards of this system can be reconstructed adequately. However, in modern presentations these high standards too often are classed as part of the seemingly strange aspects of the system. By way of digression I briefly want to comment on the well-known "esoteric interpretation" of the Epistle presented in Quispel's Commentary. It was not long ago that this interpretation was called a "convincing attempt" ${ }^{\text {s1 }}$ and there is no doubt that under certain presuppositions it is a consistent interpetation. The most important presupposition of this interpretation is that we can read "the true system" of epistle-writer Ptolemy at the beginning of Irenaeus' Adversus haereses - but, as has been said, this premise demands further detailed examination in the following chapter. A further important premise is that this exoteric text allows esoteric interpretation at all. Quispel's interpretation, which is based on those two presuppositions, modifies a central point in the Epistle made in the seventh chapter. He holds that, in his "esoteric way of reading", all three

79 In the Oxford discussion of this study, this point was especially stressed by Henry Chadwick; for the subordinating theology of trinity see Ch. Markschies, Alta Trinita Beata. Gesammelte Studien zur Trinitätstheologie, Tübingen 2000, passim.

${ }^{\prime}$ U. Kühneweg, Das neue Geserz (see note 29), 93: "Das Ergebnis dieser Bemühung (sc. Quispel's, C.M.) gibt einen tieferen Einblick in das Gesetzesverständnis des Ptolemaios, das aus dem Brief an die Flora allein so nicht zu erheben ist". 
parts of god's law only indirectly go back to the demiurge. According to Quispel, the question of the subject that had enacted god's law $(7,2:$ Tis

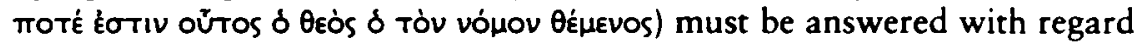
to the Aristotelic dihaeresis of causae. The demiurge in part only acts as mediator of the Sophia-Achamoth. He is only first cause of the ius talionis, which is connected to injustice; it is the pneumatic seed that is first cause of the decalogue. The seed had been inside the demiurge, but, because of his psychic being, the demiurge had not realized this circumstance. And the commandments of the ritual law in reality came from the Sophia ${ }^{82}$. It is clear that with this kind of interpretation which greatly differs from the wording of our text ${ }^{83}$, the theory of the law and the theory of principles of its author Ptolemy fits far better to Irenaeus' so-called "grande notice" which usually, against Epiphanius' text and following the Latin tradition, is taken as the Ptolemaic system. In the second, shorter main chapter of this contribution, I will mainly deal with the question whether the first nine chapters of Irenaeus' text can really be taken as sources for the reconstruction of a Ptolemaic system. But first, the chapter starts off with general remarks on the identification of Ptolemy.

\section{(II) Remarks on Ptolemaeus Gnosticus}

It is known that the Roman apologist Justin described the story of a Christian teacher called Ptolemy in his so-called "Second Apology" and reported with great sympathy Ptolemy's two steadfast confessions, which brought Ptolemy his execution. Also part of the exposition of his work is the account of a Roman Christian who had been taught by the same teacher Ptolemy and who later finally split up with her pagan husband, because she felt his permissive way of life as unbearable ${ }^{84}$. Both parts of the account are linked in the former husband's turning to the prefect of the city of Rome, Quintus Lollius Urbicus (144-160 AC), in order to

82 G. Quispel, Ptolémée, Lettre à Flora (see note 9), 28-41.

"However, Quispel can relate to a redactional passage in the so-called "grande notice" by Irenaeus, where it is said that the Valentinians divided the Prophecies (of the Old

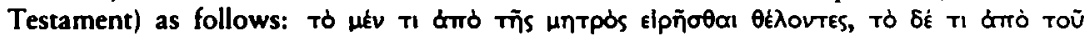

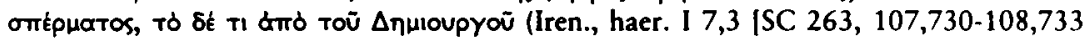
Rousseau/Doutreleau $=$ FChr 8/1, 172,3-5 Brox]; see G. Quispel, Ptolémée, Lettre à Flora [see note 9], 27 and [in agreement] U. Kühneweg, Das neue Gesetz [see note 29], 93. Different A. Rütten, Der Brief des Ptolemäus an Flora [see note 11], 66f.).

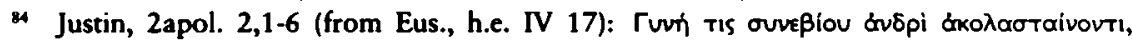

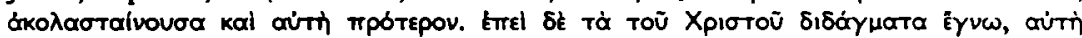

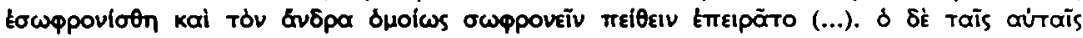

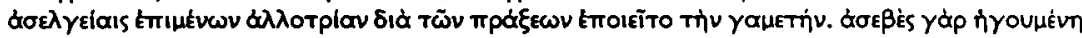

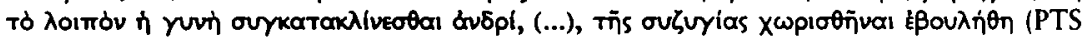
38, 137,1-10 Marcovich [with some differences to his edition]; see also the commentary in Saint Justin, Apologies. Introduction, texte critique, traduction, commentaire et index par A. Wartelle, EAug, Paris 1987, 301). 
report his former wife's teacher ${ }^{85}$. Although Justin does not give any reasons for this action, one can assume that he was led either by jealousy of the pedagogical relationship or by rage against the supposed initiator of the divorce. Of course, two questions arise at once: first, whether the two Ptolemies are identical and second, whether the unknown, divorced Roman Christian can be identified with the addressee of our Epistle, Flora.

First to the more fundamental question of the identity of the author of the Epistle to Flora and Justin's Ptolemy. It is interesting that it was only Adolf von Harnack in the year 1905 who suggested the identity of the two Ptolemy-figures and thus claimed that the Epistle dated back to a time before $152 \mathrm{AC}^{86}$. Adolf Stieren reports in his completely forgotten and also problematic dissertation on Ptolemy's Epistle, submitted to Jena University in 1843, the consensus of research from Tillemont to Neander: Nothing can be known about the person of the author. I cite the scholar of Church History at Goettingen Christian Wilhelm Franz Walch (17261784): "And it is a waste of effort to try and supplement the lack of historical knowledge by vain conjectures. We only know that he lived in the second century, because Irenaeus recalls him ${ }^{87}$. This opinion is held up to our days, eg by Barbara Aland, who believes it possible that the Epistle dated not later than from the years $170-180^{88}$. In the decades after the Second World War most authors at least considered the identity of the two Ptolemy's ${ }^{89}$. But the only scholars to speak up lastingly for this option

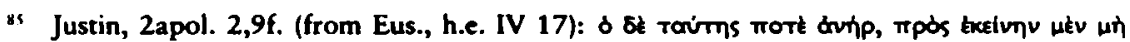

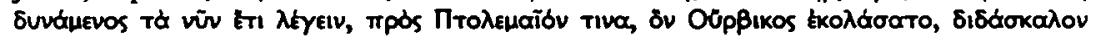

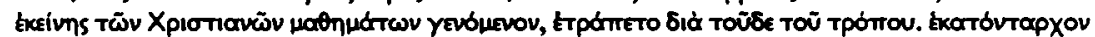

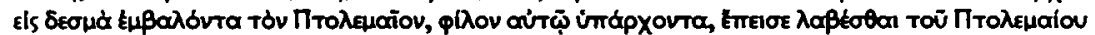

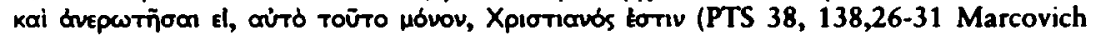
[with some differences to his edition]).

86 A.v. Harnack, Analecta zur ältesten Geschichte des Christentums in Rom, TU 28/2, Leipzig 1905, 3-5; see also id., Marcion (see note 55), 29f. and id., Die Mission und Ausbreitung des Christentums in den ersten drei Jahrhunderten, Vol. 2, Wiesbaden 1980 (= Leipzig $\left.{ }^{4} 1924\right), 599$.

87 Cf. J.G. Walch, Entwurf einer vollständigen Historie der Ketzereien, Spaltungen und Religionsstreitigkeiten, bis auf die Zeit der Reformation, TI. 1, Leipzig 1762, 388 (quotation taken from A. Stieren, De Ptolemaei Gnostici ad Floram Epistola. Pars 1 De Authentia Epistolae. Commentatio Historico-Critico, Jena 1843, 14).

8. B. Aland, Die Rezeption des neutestamentlichen Textes in den ersten drei Jahrhunderten, in: The New Testament in Early Christianity. La réception des écrits néotestamentaires dans le christianisme primitif, éd. J.-M. Sevrin, BEThL 86, Löwen 1989, (1-38) 10.

ng H. Langerbeck, Zur Auseinandersetzung von Theologie und Gemeindeglauben in der römischen Gemeinde in den Jahren 135-165, in: id., Aufsätze zur Gnosis, hg. v. H. Dörries, AAWG.PH 3/69, Göttingen 1967, (167-179) 174; B. Lohse, Meliton von Sardes und der Brief des Ptolemäus an die Flora (see note 53), 182; W.-D. Köhler, Die Rezeption des Matthäusevangeliums in der Zeit vor Irenäus, WUNT 2.R. 24, Tübingen 1987, 340; Ch. Munier, L'apologie de saint Justin, philosophe et martyr, Parad. 38, Fribourg 1994, 26-28; - for further references see G. Lüdemann, Zur Geschichte des ältesten Christentums in Rom (see note 18), 101. 
were Gerd Lüdemann in a detailed treatise ${ }^{90}$, Charles Munier, and Peter Lampe in his monography on the Christians in Rome. Lampe additionally said that Ptolemy had used 'divorce' as a central example, because his addressee had split up with her husband"'. But some time ago, Almut Rütren pointed out that, if this were the case, one wondered why the relevant topic of the divorce of mixed marriages between Christians and Non-Christians was not mentioned, although this was a question treated by the New Testament ${ }^{92}$ (eg 1Cor 7,12-16) ${ }^{93}$. Besides this, Almut Rütten showed that Jesus' reinforcement of the prohibition of divorce was also central to Marcion's argumentation against the Old Testament law ${ }^{94}$. If our remarks on the genre of the Epistle to Flora and on their AntiMarcionite orientation are correct, an interpretation of the passage on divorce in the light of Anti-Marcionite polemics, too, is far more likely than an interpretation in the light of the personal circumstances of the addressee. But this means that one reason for the identification of the two Ptolemies is lost. A sceptic position would further hold that Justin clearly identifies the Valentinians as haeretics in his "Dialogue against Tryphon" and so it would be astonishing if he stood up for the Valentinian Ptolemy without hesitation'. The fact that the Greek name 'Ptolemy' was often heard in second century Rome is another possible reason against an identity of the two Ptolemies ${ }^{96}$.

90 G. Lüdemann, Zur Geschichte des ältesten Christentums in Rom (see note 18), 100 103.114.

9 P. Lampe, Die stadtrömischen Christen (see note 31), 200-203, especially 202; different: C. Scholten, Gibt es Quellen zur Sozialgeschichte der Valentinianer Roms?, ZNW 79, 1988, (244-261) 259 and A. Rütten, Der Brief des Ptolemäus an Flora (see note 11), 59.

92 Cf. J. Jeremias, Die missionarische Aufgabe in der Mischehe (1.Kor. 7,16), in: Neutestamentliche Studien für Rudolf Bultmann zum siebzigsten Geburtstag, BZNW 21, Berlin 1954, 255-260 = id., Abba. Studien zur neutestamentlichen Theologie und Zeitgeschichte, Göttingen 1964, 292-298.

93 A. Rütten, Der Brief des Ptolemäus an Flora (see note 11), 59.

4. See the remarks on Lk 16,18: vides diversitatem legis et evangelii, Moysis et Christi (Tert., Marc. IV 34 [CChr.SL 2, 635,9f. Kroymann]) and A. Rütten, Der Brief des Ptolemäus an Flora (see note 11), 60 .

95 See Ch. Markschies, Valentinian Gnosticism (see note 8), 426-429; P. Lampe (Die stadtrömischen Christen [see note 31], 203 note 263) assumes that the Dialogue dates from ca $160 \mathrm{AD}$ and he thus believes that, when writing the (second) Apology, Justin had not identified the Valentinians as heretics yet. More restrained: G. Lüdemann, Zur Geschichte des ältesten Christentums in Rom (see note 18), 88, who concludes from dial. 35,6 (PTS 47, 129,29 Marcovich) that at any rate, Justin later on regarded Valentin(ians) as heretics.

9 In a merely chronological point of view, we know of 14 persons at that time with the name Ptolemy: H. Solin, Die griechischen Personennamen in Rom: ein Namenbuch, Corpus inscriptionum Latinarum. Auctarium, Vol. 1, Berlin/New York 1982, 221 and Vol. 3, 1337 and 1367. - Lüdemann had pointed out (before Solin's Index was edited) that among these inscriptions there were only two presumably Christian. (Zur Geschichte des altesten Christentums in Rom [see note 18], 102 note 45); in view of the low number of Christian inscriptions in the city of Rome at that time, I would restrain from drawing 
In summary, one can say that convincing arguments for an identification of Justin's couple with Ptolemy and Flora have not been found up to now and, with regard to the sources, cannot be expected"7. So Harnack's suggestion is not more than a hypothesis: not out of the question, but by no means secure. I have already treated the question of the relations of the Roman teacher Ptolemy and Valentinus presented in ancient heresiological sources in my work "Valentinian Gnosticism: Toward the Anatomy of a School"98 and I will not repeat my explanations now. I would like to concentrate on the question of the alleged "System of Ptolemy" as presented by Irenaeus.

It is known that the usual argument to take out great parts of the first eight chapters of Irenaeus' work as "grande notice" and to read it as a report on Ptolemy's system ${ }^{99}$, is found in the phrase et Ptolemaeus quidem ita in the Latin version at the end of the eighth chapter (haer. I 8,5). Meanwhile, the authoritative editions have even re-translated the phrase into Greek and have added it to the passage preserved by Epiphanius kai

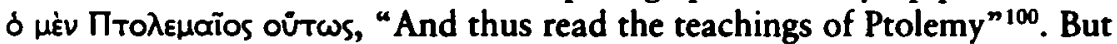
the text was not written by Epiphanius. It goes back to a later Latin translation of the fourth century, something which is blurred by modern

conclusions from these statistics. - My remarks in Valentinus Gnosticus (see note 2), 389 note 12 are misunderstood if one believes that I was convinced of the identity of the two Ptolemy figures in1992. I merely evaluated the epigraphic material differently.

97 My colleague Charles Munier (Strasbourg) very kindly discussed the question of the identification of the two persons again in our correspondence in spring 2000. First, he pointed out that the explanations in the Pastor Hermae (mand. IV 1,1-11 [GCS Apostolische Väter I, 25,22-27,5 Whittaker]) must be considered as well. As the principles laid down there concerning the way a husband should treat his wife when he finds her iv

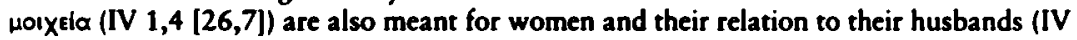
$1,8[26,20])$, and indeed this also implies the case Justin describes in 2apol. 2,1-6. Against the background of this passage in Pastor Hermae it can be understood more easily why the anonymous woman mentioned by Justin "regarded it as impious" to stay together with her husband (2apol. 2,4 [137,7]) - namely because this would have meant she became involved in her husband's sin and became "comrade of his adultery" (IV 1,5

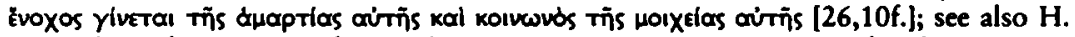
Crouzel, L'église primitive face au divorce. Du premier au cinquième siècle, ThH 13, Paris 1971, 44-56 and C. Munier, L'Apologie de saint Justin [see note 89], 28). Munier surely is right when he connects Hermas and Justin also in so far as both texts treat the special problem of divorces for reasons of aduitery in a more casuistic way, while Marcion and Ptolemy are dealing with far more fundamental questions. But all this means that a comparison between Justin and Ptolemy must be carried out with great care, as completely different contexts are regarded.

9 The term "grande notice" alludes to F.M.-M. Sagnard, La gnose Valentinienne et le témoignage de Saint Irénée, Études de philosophie médiévale 36, Paris 1947, 31.140144. - Sagnard also treated the Epistle of Ptolemy in detail: La gnose Valentinienne et le témoignage de Saint Irénée, 451-479.

100 Thus eg A. Rousseau and L. Doutreleau (SC 264, 137, $972 f$.; see the commentary SC 263, 218 ) and - following them without any explanations - N. Brox (FChr 8/1, 186), but not in the Epiphanius-edition by Karl Holl (GCS Epiphanius I, 427,26-28). 
editions. And the well known ending of the "grande notice" can be recognized as a late remark written by a redactor of the Latin version of Irenaeus' text. It does not go "parfaitement" with the previous aútais $\lambda \dot{\varepsilon} \xi \varepsilon \sigma 1 \lambda \dot{\varepsilon}$ yovtes oưtws (beginning of I 8,5). One instance uses the singular form (Ptolemaeus) and the other one the plural (qui sunt circa Ptolemaeum $)^{101}$. Adelin Rousseau and Louis Doutreleau claim in their Commentary that Epiphanius deleted this note on Ptolemy, because he wanted the text to be part of his report on Valentinus (haer. 31,9,1-32,9). However, the redactional final notice of the paragraph cited from Irenaeus shows ${ }^{102}$ that obviously Epiphanius did not know that this was a text written by Ptolemy. Otherwise he would have chosen to write another paragraph on Ptolemy later on in his work (haer. 33) in a different way. In that paragraph, Irenaeus ascribed quite a different Valentinian report as teachings to the Gnostics ${ }^{103}$. So one can almost be sure that the text is a secondary (and factually incorrect) gloss ${ }^{104}$. One can even increase the plausibility of the argumentation, which concentrated mainly on the text of the redactional Latin gloss and the context in Epiphanius' work, by taking a closer look at Irenaeus' prescript. There the Bishop of Lyon stated that in the following work he was going to deal with treatises written by people who called themselves "followers of Valentinus"; their treatises had come to his notice. And he wished only within the limits of his powers to talk on the teachings of the "people around Ptolemy", on "a branch of Valentinus' school" ${ }^{105}$. As I have said in my work mentioned, this differ-

101 See A. Rousseau, SC 263,218 on haer. I 8,5 $(136,189)$ or $8,5(129,909 f)$. For a short notice on the problem see Ch. Markschies, Valentinus Gnosticus (see note 2), 365 note 119 and in greater detail G. Lüdemann, Zur Geschichte des ältesten Christentums in Rom (see note 18), 99. For a critical study of the passage see Carola Barth, Die Interpretation des Neuen Testaments in der valentinianischen Gnosis, TU 37/3, Leipzig 1911, 19, and G. Lüdemann, aaO. 99 note 36.

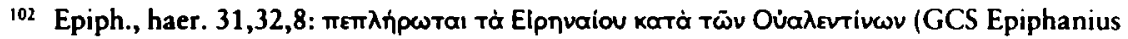
I, 435,9 Holl).

103 Epiph., haer. 33,1,2-2,5 (448,8-450,6) = Iren., haer. I 12,1 (181,1-182,16).

104 1 am aware that in this context of course comparable Latin phrases with which the report of different positions is framed in the Latin translation of Irenaeus must be examined and discussed. The Latin notice Haec quidem ille (Iren., haer. I 11,1 [SC 264, 170,37]) which

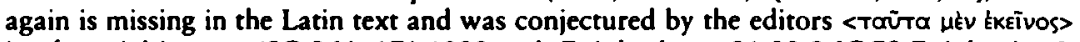
is of special interest (SC 264, 171,1233; vgl. Epiph., haer. 31,32,9 [GCS Epiphanius I, $435,8 \mathrm{Holl}]$ ). As the editors do not mention the connection of the textual situation with haer. I 8,5, they state: "Epiphane a volontairement omis ces mots, dont il n'y a aucune raison de suspecter l'authenticité irénéenne" (SC 263, 231); but see also V 33,4 (SC 153, 416,86-88). More detailed remarks such as haer. I 13,7 (SC 264, 204,127-133) = Epiph., haer. 34,3,10 (GCS Epiphanius II, 9,24-10,1 Holl/Dummer) or IV 32,1 (SC 100, 796,13 ) or preliminary remarks as haer. I 30,15 (SC 274, 277) of course must be distinguished. I will come back to this in greater detail in the mentioned new edition I am planning to publish.

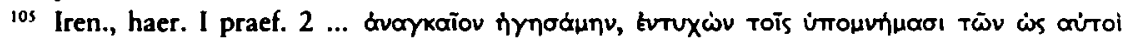

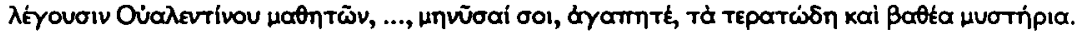

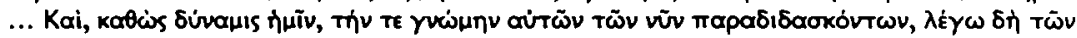

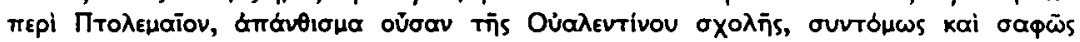


entiation must be taken seriously. The "people around Ptolemy" (oi mepi

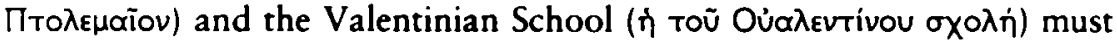
be differentiated ${ }^{106}$. And so the question arises, whether Irenaeus did have the power to carry out a detailed refutation of the school of Ptolemy in his work, or whether he more or less left it to the announcement in the prescript and to a few instances of polemics. It can be said for this that in the first book there is only one instance to be found where the opinion of "the people around Ptolemy" is reported (haer. I 12,1 ${ }^{107}$ ), but otherwise the Roman teacher is only mentioned in name lists of heretics and in similar contexts. In conclusion: I am convinced that the "grande notice" in Irenaeus' first eight chapters reports the system of those people who call themselves followers of Valentinus. Presumably, Irenaeus found the notice in their treatises and quoted it from there. All this has little to do with the teachings of the people around Ptolemy - at least according to Irenaeus. One could further support these text-immanent reasons with a detailed comparison of Ptolemy's Epistle to Flora and the "grande notice". I refrain from this comparison now, because the crucial differences have been presented in works by other colleagues and myself.

These observations are not the sum total of what can be said on a reflection made by Winrich Löhr in his fundamental article on Ptolemaeus in the "Theologische Realenzyklopädie": W. Löhr says it can be assumed that in haereses I $1-8$, elements of teachings can be found that go back to Ptolemy or were inspired by him directly, but that drawing a line between teacher Ptolemy and his followers remains difficult ${ }^{108}$. If our observations on the "grande notice" and the secondary character of the gloss et Ptolemaeus quidem ita are correct, such a differentiation is even more difficult. Of course, it remains the task of defining a doxographic tradition out of different pieces of information on Ptolemy by

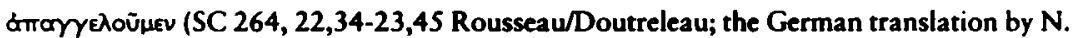
Brox in FChr 8/1, 125 makes the grammatical structure unclear). The Latin translation follows the Greek text verbatim: Et quantum nobis virtutis adest (22,42f.). A connection

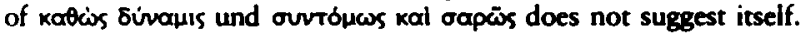

106 I was reproached twice for having used the wordings ol mepl ... and ol \&uథi ... without explanations and for translating these wordings philologically incorrectly, for excluding the person in the genitive (eg Valentinus or Ptolemy) from the group. I admit that the first approach is correct. However, later on, I have given two instances of this meaning of the prepositions in the early Empire; but it is correct that this meaning was not possible in Classical Greek: Ch. Markschies, Valentinian Gnosticism (see note 8), 414 note 53 and id., Nachrichten und Termine, ZAC 3, 1999, 150-151. - The question has been treated in detail by $\mathrm{G}$. Lüdemann, Zur Geschichte des ältesten Christentums in Rom (see note $18)$, 97f. with notes $32 \mathrm{f}$.

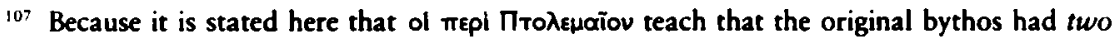
syzygies (Ennoia and Thelesis: p. 181,1-4 Rousseau/Doutreleau), a slight difference can be found in comparison with the position in the "grande notice", which states he had only one syzygy, the ennoia, also called charis and sige (haer. I 1,1 [29,79f.]).

108 W.A. Löhr, Art. Ptolemäus (see note 10), 699-702. - Discussed in greater detail in W.A. Löhr, La doctrine de dieu (see note 10), 190f.; there, he also discusses a theological development of Ptolemy. This explanation for our observations of course must be taken into consideration, too. 
Irenaeus, Tertullian and Epiphanius which are not identical with what we know from his Epistle to Flora. However, this task is too extensive to be carried out in this contribution.

Of all this follows that the only reliable source for a reconstruction of the teachings of the Roman theologian Ptolemy is the Epistle to Flora. The system developed in Irenaeus' so-called "grande notice" cannot be called "Ptolemaeic" without further thought and, accordingly, the Epistle cannot be interpreted in the light of this system. On the contrary: This procedure disregards the rare records that allow a reconstruction of the history of development of Valentinian Gnosticism from Valentinus to Ptolemy and further on to the circles of followers described in Irenaeus' works. These rare records, connected with the results of my interpretation, allow the hypothesis that Ptolemy was closer to the consent of the theology of the city of Rome than his followers - similar to the namegiving Valentinus, who was closer to the consent of Alexandrine Theology than his followers. From this hypothesis two conclusions follow: first, Valentinus and Ptolemy are likely to be closer connected than I claimed in my book seven years ago ${ }^{109}$. And second, the real originators of the "classical" Valentinian myth are neither Valentinus nor Ptolemy, but gifted and imaginative thinkers among their followers of whom we do not know the names.

One final remark: Already in the first edition of his Commentary on Ptolemy's Epistle of the year 1949, Quispel mentioned the topic of a "mentalité gnostique" ${ }^{\text {"110 }}$. And although I differ from our Dutch colleague in what regards the position of the Epistle in the history of Christian theology of the second century, in view of modern historiographical developments the question remains relevant, of what sort of "mentality" the Epistle gives evidence. In view of my detailed interpretation of the text, I believe I can make it brief here: It has become clear that in his Epistle to Flora, Ptolemy very closely follows literary conventions and argumentative standards of the philosophy of his time; that he tries to solve a theological problem, raised by biblical texts, with the help of a philosophical method and philosophical figures of thinking, eg the dialectics of

109 The most important thematic parallel between Ptolemy and Valentinus seems to be the remark alluding to the relationship of father and son and seeing the true creator of the

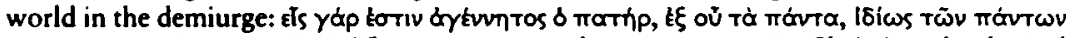

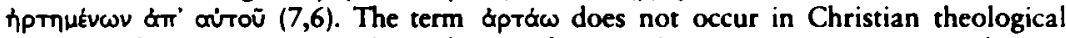
contexts (cf. Lampe, PGL s.v.), but only in profane Greek texts (see LSJ s.v., eg Porphyrius, sent. 14 [BiTeu 6,12.14 Lamberz]) in order to describe the depending of things on reasons. Although the supreme god is not the creator of all things, still all is dependent on him. This exactly is a central point in one of Valentin's texts. He puts this idea in

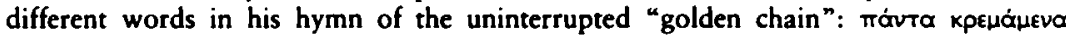
(Hipp., haer. VI 37,7 [GCS Hippolytus III, 167,17 Wendland]; see Ch. Markschies, Valentinus Gnosticus [see note 2]: for the text p. 218 and commentary p. 232-238).

110 G. Quispel, Ptolémée, Lettre à Flora (see note 9), 7. 
freedom and necessity. Nevertheless, in view of his constant use of the authority of the Scriptures as an argument, it would not be very accurate to describe him as a "Christian philosopher". So it must be said that one does not learn a lot about a "mentalité gnostique" from "Ptolemy's Epistle to Flora", but a lot about the mentality of the group of Christian theologians in the second century to which the Apologists and mainly Justin belonged. Ptolemy's insisting on the "teachings of the saviour" and the "apostolic tradition" - terms which run through his work from beginning to end $(7,9)$ - goes with this ${ }^{111}$. Many decades ago, Eduard Norden, scholar of Graecism in Berlin, characterized the text in a brief outline in the following way: "The Epistle is a masterpiece in both, in its development of reasoning, satiated by Platonic treatises, and in its stylization. ${ }^{n 12}$. These praising words could be followed by the critical question, how well the author really knew the Septuagint, the Old Testament law he was dealing with ${ }^{113}$. But the answer to this question again would confirm the picture we drew of the author. Finally, I would like to stress that with this interpretation of a text that usually is forced into a common framework of "Valentinian Gnosticism", I do not mean to present a "degnostification" of definitely Gnostic texts ${ }^{114}$. I only mean to work on a precise historical description of the conditions of formation of Valentinian Gnosticism in the second century. I close and hope to have contributed to that description.

\section{ZUSAMMENFASSUNG}

Der Aufsatz untersucht den Brief, den der römische Theologe Ptolemaeus an die Matrone Flora geschrieben hat, und versucht, ihn soweit als möglich aus sich selbst heraus zu verstehen. Ein erster Abschnitt behandelt die Gattung des Briefes und weist nach, daß er ein eisagogisches Lehrschreiben in Briefform darstellt und sich an der Form einer dihaeretischen Eloorwyth orientiert. In einem zweiten Abschnitt wird die Gliederung des Textes untersucht und gezeigt, daB die beiden Themen des Schreibens, Gesetzes-

'II See H. Freiherr von Campenhausen, Kirchliches Amt und geistliche Vollmacht in den ersten drei Jahrhunderten, BHTh 14, Tübingen 1963, 2nd ed., 172-176.

112 E. Norden, Die antike Kunstprosa vom VI. Jahrhundert bis in die Zeit der Renaissance, Vol. 2, Darmstadt, Sth ed., 1958 (Leipzig 3rd ed., 1915), 920.

113 See A. Rütten, Der Brief des Ptolemäus an Flora (see note 11), 69: "Aus dem Brief an Flora geht hervor, daB Ptolemäus mit Sicherheit nicht mit der Septuaginta gearbeitet hat. Es ist zu fragen, wie seine Kennenis des Pentateuch überhaupt beschaffen war, und ob sie nicht sogar ausschließlich über einige neutestamentliche Schriften vermittelt ist" ${ }^{n}$. E. Norden had pointed to stilistic corrections of two biblical texts due to the demands of the rhythmical endings of sentences. (Die antike Kunstprosa, Vol. 2, 922: Lev 20,9 = ep. Flor. 5,7), but in both cases it were phrasings already found in the New Testament: see Mt 15,4 or Mt $15,8 f$. So it were Norden's examples which made it seem highly probable that Ptolemy had used the New Testament rather than the Septuagint for his citations. (For the use of the Bible see B. Aland, Die Rezeption des neutestamentlichen Textes [see note 88], 6-14.)

114 Different J. Helderman, A Christian Gnostic Text (see note 4), 57. 
lehre und Prinzipientheorie, zusammenhängen und ihre Behandlung durch die Erfordernisse der Gattung geprägt ist. Dagegen sind die theologischen Lösungen, die Ptolemaeus in beiden Bereichen vertritt, wie durch Vergleich zu anderen zeitgenössischen Autoren nachgewiesen wird, originell. In einem dritten Abschnitt wird nach diesen Besonderheiten der Prinzipientheorie und insbesondere nach dem Verhältnis von Demiurg und owtrip gefragt. Der Schlußabschnitt setzt die aus dem Brief rekonstruierte Theologie des Ptolemaeus in Beziehung zu anderen christlichen Theologien des zweiten Jahrhunderts und benennt philologische, historische und inhaltliche Gründe, warum die $n g r o ß e$ Notiz $^{\star}$ aus Irenaeus auf die Schüler des Ptolemaeus zurückgeht und nicht für den historischen Ptolemaeus in Anspruch genommen werden darf. 